\title{
Cytotoxicity and bacterial membrane destabilization induced by Annona squamosa L. extracts
}

\author{
NÍCOLAS C.C. PINTO ${ }^{1}$, JUCÉLIA B. SILVA ${ }^{1}$, LAURA M. MENEGATI ${ }^{1}$, MARIA CLARA M.R. \\ GUEDES $^{1}$, LUCAS B. MARQUES ${ }^{2}$, THIAGO P. DA SILVA ${ }^{3}$, ROSSANA C.N. DE MELO ${ }^{3}$, ELAINE M. \\ DE SOUZA-FAGUNDES ${ }^{2}$, MARCOS J. SALVADOR ${ }^{4}$, ELITA SCIO ${ }^{1}$ and RODRIGO L. FABRI ${ }^{1}$ \\ ${ }^{1}$ Laboratório de Produtos Naturais Bioativos, Departamento de Bioquímica, Instituto de Ciências Biológicas, Universidade \\ Federal de Juiz de Fora, Rua José Lourenço Kelmer, s/n, São Pedro, 36036-900 Juiz de Fora, MG, Brazil \\ ${ }^{2}$ Departamento de Fisiologia e Biofísica, Instituto de Ciências Biológicas, Universidade Federal de \\ Minas Gerais, Av. Antônio Carlos, 6627, Pampulha, 31270-901 Belo Horizonte, MG, Brazil \\ ${ }^{3}$ Laboratório de Biologia Celular, Departamento de Biologia, Instituto de Ciências Biológicas, Universidade \\ Federal de Juiz de Fora, Rua José Lourenço Kelmer, s/n, São Pedro, 36036-900 Juiz de Fora, MG, Brazil \\ ${ }^{4}$ Departamento de Biologia da Planta, Universidade Estatual de Campinas, Cidade \\ Universitária Zeferino Vaz, 13083-970 Campinas, SP, Brazil
}

Manuscript received on October 5, 2015; accepted for publication on May 4, 2016

\begin{abstract}
This study aimed to further investigate the cytotoxicity against tumor cell lines and several bacterial strains of Annona squamosa and its mode of action. Methanol extracts of A. squamosa leaves (ASL) and seeds (ASS) were used. ASL showed significant antibacterial activity against $S$. aureus, K. pneumoniae and E. faecalis with MIC values of 78, 78 and $39 \mu \mathrm{g} / \mathrm{mL}$ respectively. Moreover, ASL exhibited significant biofilm disruption, rapid time dependent kinetics of bacterial killing, increased membrane permeability and significantly reduced the cell numbers and viability. Regarding the cytotoxicity against tumor cell lines, ASS was more active against Jurkat and MCF-7 cells, with $\mathrm{CI}_{50} 1.1$ and $2.1 \mu \mathrm{g} / \mathrm{mL}$, respectively. ASL showed promising activity against Jurkat and HL60, with $\mathrm{CI}_{50} 4.2$ and $6.4 \mu \mathrm{g} / \mathrm{mL}$, respectively. Both extracts showed lower activity against VERO cells and reduced the clonogenic survival at higher concentrations $\left(\mathrm{IC}_{90}\right)$ to MCF-7 and HCT-116 lineages. The alkaloids anonaine, asimilobine, corypalmine, liriodenine nornuciferine and reticuline were identified in extracts by UPLC-ESI-MS/MS analysis. This study reinforced that $A$. squamosa presents a remarkable phytomedicinal potential and revealed that its antimicrobial mechanism of action is related to bacterial membrane destabilization.
\end{abstract}

Key words: alkaloids, Annona squamosa, antibacterial, citotoxicity, herbal medicine.

\section{INTRODUCTION}

Although the use of medicinal plants is an ancient practice, nowadays it is still considered the main strategy to treat several diseases in a variety of

Correspondence to: Rodrigo Luiz Fabri

E-mail: rodrigo.fabri@ufjf.edu.br ethnic groups and communities in many countries (Sharma and Kumar 2011). In this context, the ethnopharmacology has contributed significantly to the studies aimed to evaluate the biological effects of medicinal plants, corroborating the practice of herbal traditional medicine (Coutinho et al. 2004, Oliveira et al. 2004). It is estimated that medicinal 
plants are used as the primary health care by $80 \%$ of the population in developing countries (Brasil 2006, Rosa et al. 2011). Besides, many studies have demonstrated that natural products continue to play a highly significant role in the drug discovery and development process (Newman and Cragg 2010).

In the recent years, the frequency of microbial resistance and its association with serious infectious diseases have increased gradually, so that the search for new therapeutic tools is needed (Padua et al. 2013). A classical example of an emergent microorganism is methicillin resistant Staphylococcus aureus (MRSA), which is virtually resistant to all antibiotics, except for vancomycin (Rossi 2011). Not less important, cancer, caused by disorders on cell proliferation, is the second leading cause of death in the world, the first in developed countries, and its mortality will probably continue to increase in the next years (Brandão et al. 2010, Jemal et al. 2011). However, the drugs currently available to treat those conditions present a variety of side effects and are not effective in many situations. Therefore, much attention has been given to plant extracts and their isolated compounds in the search for new therapeutic agents (Almeida et al. 2005, Gurib-Fakim 2006).

The Annonaceae family consists of approximately 120 genera which have tropical and subtropical distribution worldwide (Joly 1979). According to Fouque (1972), this family is native to tropical America. The species Annona squamosa L. is cultivated in tropical South and Central America, and occasionally in Florida. The fruits are commonly used as food, as they are considered an important source of vitamin $\mathrm{C}$ and minerals, including potassium, calcium and phosphorus (Gupta et al. 2005). In traditional medicine, the leaves, seeds and fruits of this species are considered as antidiarrheal, antitumor, antimicrobial and anthelmintic remedies (Lorenzi and Matos 2002, Rieser et al. 2004). Some phytochemical and pharmacological studies of A. squamosa seeds, including hypoglycemic, antiovulatory and insecticidal activities had been reported (Fouque 1972, Vohora et al. 1975)

Rahman et al. (2005) showed the antibacterial activity of four different extracts of $A$. squamosa seeds and Kotkar et al. (2002) reported the antimicrobial activity of flavonoids isolated from the seeds. However, these activities were evaluated only by preliminary tests, such as agar diffusion method. In addition, some studies have reported the cytotoxic activity of $A$. squamosa seeds extracts, however, the biological activities of the leaves are less studied (Pandey and Barve 2011). Thus, the aims of the present study were to further investigate the cytotoxic actions and antibacterial activity of A. squamosa seeds and leaves, and to evaluate whether its antimicrobial mechanism of action is related to bacterial membrane destabilization. Also the chemical characterization of alkaloids from the extracts was performed by UPLC-ESI-MS/MS analysis.

\section{MATERIALS AND METHODS}

\section{PLANT MATERIAL}

Annona squamosa L. leaves and seeds were collected in Recreio, Minas Gerais State, Brazil, in March, 2011. The plant was identified by Dr. Luciana Moreira Chedier from Federal University of Juiz de Fora. A voucher specimen (CESJ 46005) was deposited at the Herbarium Leopoldo Krieger of Federal University of Juiz de Fora.

\section{PREPARATION OF THE EXTRACTS}

Oven dried $\left(40{ }^{\circ} \mathrm{C}\right.$ for two days) and powdered leaves and seeds of the plant $(6.5 \mathrm{~g}$ and $3.3 \mathrm{~g}$, respectively) were extracted by static maceration with methanol ( 5 x $200 \mathrm{ml})$ for five days at room temperature. The solvent was evaporated using a rotatory evaporator $\left(40{ }^{\circ} \mathrm{C}\right)$ to produce the methanolic extracts with yield to $6.6 \%$ and $11.4 \%$, respectively for leaves (ASL) and seeds (ASS). The extracts were kept in tightly stoppered bottles under 
refrigeration until used for the biological testing and chemical analysis.

\section{UPLC-ESI-MS/MS ANALYSIS}

ASL and ASS were analyzed on an Acquity UPLC system (Waters ${ }^{\circledR}$, Milford, MA, USA) using a UPLC column $(2.1 \times 50 \mathrm{~mm}, 1.7 \mu \mathrm{m}$ particle size) at a temperature of $30{ }^{\circ} \mathrm{C}$. A gradient of (A) deionized purified water with $1 \%$ formic acid and (B) methanol (Tedia ${ }^{\circledR}$, Brazil) starting with $20 \%$ $\mathrm{B}$ and ramping to $100 \% \mathrm{~B}$ at $5 \mathrm{~min}$, holding to $5.50 \mathrm{~min}$, then returning to initial conditions and re-equilibrating at $7 \mathrm{~min}$. Detection in positive ion modes was achieved on an Acquity TQD mass spectrometer (Micromass Waters ${ }^{\circledR}$, Milford, MA, USA) with capillary voltage-3,000 V, Cone-30 V, source temperature $150^{\circ} \mathrm{C}$; desolvation temperature $350{ }^{\circ} \mathrm{C}$. In the identification of the detected compounds, the chromatographic retention time (co-injection of the standards method) and the MS/ MS data and spectrums of the standard compounds were compared with retention time and spectrums of the extract for confirmation. Previously, the ion of interest was subjected to MS/MS analysis to make sure that the $\mathrm{m} / \mathrm{z}$ corresponded to the same compound as the standard by direct insertion mass spectrometry with electrospray ionization in positive ion mode (ESI-MS/MS). The analyses were carried out at least in triplicate.

\section{MICROBIAL STRAINS}

The samples were evaluated against a panel of micro-organisms, Staphylococcus aureus (ATCC 6538), Enterobacter aerogenes (ATCC 13048), Enterobacter cloacae (ATCC 23355), Klebsiella pneumoniae (ATCC 4552), Pseudomonas aeruginosa (ATCC 9027), Bacillus cereus (ATCC 14579), Enterococcus faecalis (ATCC 19433), Shigella dysenteriae (ATCC 13313), Escherichia coli (ATCC 10536), Salmonella typhimurium (ATCC 13311), and Salmonella choleraesuis
(ATCC 10708). These strains were cultured overnight at $37^{\circ} \mathrm{C}$ in Mueller Hinton agar (MHA).

SERIAL DIUTION ASSAY FOR DETERMINATION OF THE MINIMAL INHIBITORY CONCENTRATION (MIC)

The minimal inhibitory concentration (MIC) of each sample was determined by using broth microdilution techniques as described by CLSI (2010). MIC values were determined in Mueller Hinton broth (MHB). Bacteria were cultured overnight at $37^{\circ} \mathrm{C}$ for $24 \mathrm{~h}$ in Mueller Hinton Agar (MHA). Samples stock solutions were two-fold diluted from 5000 to $2.5 \mu \mathrm{g} / \mathrm{mL}$ (final volume $=80$ $\mu \mathrm{L}$ ) and a final DMSO concentration $1 \%$. Then, $100 \mu \mathrm{L}$ of MHB were added onto microplates. Finally, $20 \mu \mathrm{L}$ of $10^{6} \mathrm{CFU} / \mathrm{mL}$ (according to McFarland turbidity standards) of standardized bacterial suspensions were inoculated onto microplates and the test was performed in a volume of $200 \mu$ l. Plates were incubated at $37{ }^{\circ} \mathrm{C}$ for $24 \mathrm{~h}$. The same tests were performed simultaneously for growth control (MHB + bacteria) and sterility control (MHB + extract). Chloramphenicol (500 to $0.24 \mu \mathrm{g} / \mathrm{mL}$ ) was used as positive control. The MIC values were calculated as the highest dilution showing complete inhibition of tested strain. The analyses were performed in duplicate. Extracts with MIC values $\leq 100 \mu \mathrm{g} / \mathrm{mL}$ were considered significantly active (Kuete 2010).

\section{MINIMUM BACTERICIDAL CONCENTRATION (MBC)}

The MBC of the plant extracts was determined by a modification of the method of Spencer and Spencer (2004). Samples (10 $\mu \mathrm{L})$ were taken from plates with no visible growth in the MIC assay and inoculated on freshly prepared Mueller-Hinton agar plates, and later incubated at $37{ }^{\circ} \mathrm{C}$ for $24 \mathrm{~h}$. The MBC was taken as the concentration of the extract that did not show any growth on a new set of agar plates. 


\section{EFFECT ON ESTABLISHED BIOFILMS}

The effect on established biofilms was verified as described by Nostro et al. (2007) with some modifications. S. aureus (ATCC 6538), K. pneumoniae (ATCC 4552) and E. faecalis (ATCC 19433) strains were grown as biofilms using TSB with $1 \%$ glucose in 96 well polystyrene microtitre plates for $24 \mathrm{~h}$ at $37^{\circ} \mathrm{C}$. Then the planktonic-phase cells were gently removed, the wells were washed three times with PBS pH 7.4 and filled with $200 \mu \mathrm{L}$ twofold dilutions of ASL, ranging from the MIC to a 4-fold dilution of the MIC. The plates were incubated for $24 \mathrm{~h}$ at $37{ }^{\circ} \mathrm{C}$. The optical density at $492 \mathrm{~nm}$ was measured at time 0 and after incubation for $24 \mathrm{~h}$. Chloramphenicol and ciprofloxacin (MIC values) were used as positive controls. Biofilm control consisting of TSB medium and inoculum was included. The experiment was carried out in triplicate. The percentage of inhibition of the established biofilm was defined as follows: (mean $\mathrm{OD}_{492}$ of control well - mean $\mathrm{OD}_{492}$ of treated well) / mean $\mathrm{OD}_{492}$ of control well\} x 100 .

\section{BACTERIAL KILLING ASSAY}

ASL was tested to determine the time-kill kinetics for $S$. aureus (ATCC 6538), K. pneumoniae (ATCC 4552) and E. faecalis (ATCC 19433) strains. Freshly grown bacterial strains about $10^{8}$ cells $/ \mathrm{mL}$ in saline were inoculated in tubes of Mueller Hinton broth supplemented with different concentrations of ASL (MIC, $0.5 \mathrm{MIC}$ and $0.25 \mathrm{MIC}$ values) at $37{ }^{\circ} \mathrm{C}$ and optical density at $600 \mathrm{~nm}$ was recorded at 2, 4, 6, 8 and $24 \mathrm{~h}$. Graphs were plotted based on variations in turbidity along the hours of incubation. This obtained growth rate was studied for any signs of bactericidal effects of ASL. Chloramphenicol and ciprofloxacin (MIC values) were used as positive controls. Bacterial strains inoculated in MHB and ASL vehicle served as control of bacterial growth. The experiment was carried out in triplicate (Datta et al. 2011).

\section{OUTER MEMBRANE PERMEABILITY}

Outermembrane (OM) permeabilitywas determined according to the method described by Hao et al. (2009), with some modifications. The strains used were $K$. pneumoniae (ATCC 4552) and E. faecalis (ATCC 19433). Briefly, overnight cultures $\left(5 \times 10^{7}\right.$ $\mathrm{CFU} / \mathrm{mL}$ ) were inoculated into Mueller-Hinton broth containing ASL alone and the hydrophobic antibiotic erythromycin concentrations ranging from 0.1 to $20 \mu \mathrm{g} / \mathrm{mL}$ with or without ASL (MIC value). The media were then added to sterilized 96well microplates and incubated at $35{ }^{\circ} \mathrm{C}$ for $24 \mathrm{~h}$. The growths of bacteria were measured at $450 \mathrm{~nm}$ using a spectrophotometer.

\section{NUCLEOTIDE LEAKAGE}

The experiment was performed according to Tang et al. (2008) with some modifications. The overnight culture of S. aureus (ATCC 6538), K. pneumoniae (ATCC 4552) and E. faecalis (ATCC 19433) at 37 ${ }^{\circ} \mathrm{C}$ was washed and resuspended in $10 \mathrm{mM}$ PBS $(\mathrm{pH} 7.4)$, reaching the final density of about $10^{8}$ cells $/ \mathrm{mL}$. Strains were incubated with ASL (MIC value) for different times (2, 4, 6 and $8 \mathrm{~h})$; strains incubated with $10 \mathrm{mM}$ PBS ( $\mathrm{pH}$ 7.4) were used as control. Following incubation, the cell suspensions were centrifuged at 10,000 rpm for $10 \mathrm{~min}$ and the supernatants were then diluted appropriately and the optical density at $260 \mathrm{~nm}$ was recorded at room temperature $\left(25^{\circ} \mathrm{C}\right)$. The experiment was carried out in triplicate.

\section{BACTERIA QUANTIFICATION}

Bacteria enumeration was performed in cytocentrifugation preparations as previously described by Silva et al. (2014). Bacterial strains of $S$. aureus (ATCC 6538), K. pneumoniae (ATCC 4552) and E. faecalis (ATCC 19433) in saline were inoculated in tubes contained Mueller Hinton broth (MHB) and ASL (MIC value). Control was inoculated in MHB and ASL vehicle. Treated and 
control cultures, in triplicate, were incubated at 35 ${ }^{\circ} \mathrm{C}$ for $24 \mathrm{~h}$. Samples were diluted 10 times $(1 \mathrm{~mL})$ in saline, fixed with free-particle $37 \%$ formaldehyde $(0.2 \mu \mathrm{m}$ filtered) to a final concentration of $2 \%$, stained with DAPI (final concentration $0.01 \mu \mathrm{g}$ / $\mathrm{mL}$ ) and placed in mega funnels (Shandon Mega funnel, Thermo, UK) for immediate centrifugation in a cytocentrifuge (Shandon Cytospin 4, Thermo, United Kingdom), at $452 \mathrm{~g}$ at high acceleration for $10 \mathrm{~min}$. Acceleration and speed were established as the procedures for medical microbiology provided by the Cytospin manufacturer manual. Analyses were performed on a fluorescence microscope (BX60, Olympus, Melville, NY, USA) and U-MWU2 filter (330-385 $\mathrm{nm}$ excitation wavelengths). Bacteria numbers were determined by counting 20 random fields at 1,000x magnification using an ocular grid. The final count was determined by multiplying by the dilution factor (10x).

\section{BACTERIA VIABILITY}

For evaluation of bacteria viability, freshly grown bacterial strains of $S$. aureus (ATCC 6538), $K$. pneumoniae (ATCC 4552) and E. faecalis (ATCC 19433) in saline were inoculated in tubes containing MHB and ASL (MIC value) and incubate at $35^{\circ} \mathrm{C}$ for $24 \mathrm{~h}$. Bacterial strains inoculated in MHB and ASL vehicle were used as control. Bacterial samples (diluted 10 times in saline) were stained with the LIVE/DEAD BacLight kit (Molecular Probes) which enable differentiation between bacteria with intact and damaged cell membranes (Boulos et al. 1999, Freese et al. 2006). This kit contains a mixture of fluorescent stains (SYTO 9 and propidium iodide) that differ both in their spectral characteristics and their ability to penetrate healthy bacterial cell membranes. SYTO 9 stains viable cells whereas propidium iodide stains non-viable cells. Bacteria were stained by adding $1 \mathrm{~mL}$ of each sample to 3 $\mu \mathrm{L}$ of BacLight. In the dark, samples were placed in megafunnels (Shandon Mega funnel, Thermo, UK) for immediate centrifugation in a cytocentrifuge as described above. Samples were prepared by using regular slides without any coating. Analyses were performed on a fluorescence microscope (BX-60, Olympus, Melville, NY, USA) using U-MWB filter (450-480 $\mathrm{nm}$ excitation wavelengths) which allows simultaneous visualization of both markers. Bacteria were directly counted in 10 random fields using an ocular grid at 1,000x magnification and the average percentage of live/dead bacteria was established for each slide sampled.

\section{HUMAN TUMOR CELL LINES}

Four human tumor cell lines were used, Jurkat (human immortalized line of T lymphocyte), HL60 (human promyelocytic leukemia), MCF-7 (breast cancer) and HCT-116 (colorectal carcinoma). The VERO lineage (African green monkey kidney cells) was used as a model of non tumor cells. All lineages were maintained in the logarithmic phase of growth in RPMI 1640 or D-MEM supplemented with $100 \mathrm{IU} / \mathrm{mL}$ penicillin and $100 \mu \mathrm{g} / \mathrm{mL}$ streptomycin enriched with $2 \mathrm{mM}$ of L-glutamine. Leukemia cells were cultured in RPMI and 10\% of fetal bovine serum. The adherent cells were maintained in D-MEM enriched with $5 \%$ of fetal bovine serum. All cultures were maintained at 37 ${ }^{\circ} \mathrm{C}$ in a humidified incubator with $5 \% \mathrm{CO}_{2}$ and $95 \%$ air. The media were changed twice weekly and the cells were regularly examined. All cell lines were used until 20 passages.

\section{EVALUATION OF CYTOTOXIC EFFECT AGAINST HUMAN TUMOR CELL LINES}

Tumor cell lines (Jurkat, HL60, MCF-7 and HCT) were inoculated at $1 \times 10^{4}$ cells (MCF-7, HCT116 and VERO), $5 \times 104$ cells (HL60) and $1 \times$ $10^{5}$ cells (Jurkat) per well. The plates were preincubated for $24 \mathrm{~h}$ at $37^{\circ} \mathrm{C}$ to allow adaptation of cells prior to the addition of the test compounds. ASL and ASS were dissolved in dimethyl sulfoxide (DMSO) prior to dilution. The half maximal 
effective dose $\left(\mathrm{ED}_{50}\right)$ was determined over a range of concentrations (nonserial six dilutions: from 50 to $1.5 \mu \mathrm{g} / \mathrm{mL}$ ). All cell cultures were incubated in a $5 \% \mathrm{CO}_{2} / 95 \%$ air-humidified atmosphere at 37 ${ }^{\circ} \mathrm{C}$ for $48 \mathrm{~h}$. Negative control included treatment with $0.5 \%$ DMSO. Cell viability was estimated by measuring the rate of mitochondrial reduction of tetrazolium-dye (MTT). All samples were tested in triplicate, in three independent experiments (Monks et al. 1991). The cytotoxicity of etoposide and doxorubicin were evaluated under the same experimental conditions as positive controls.

\section{DNA FRAGMENTATION ASSAY}

Cell cycle status and quantification of DNA fragmentation (hypodiploid DNA-content) were performed by propidium iodide (PI) staining according to Ricardi and Nicolleti (2006). Cells were treated with the samples at $20 \mu \mathrm{g} / \mathrm{mL}$ in a $5 \% \mathrm{CO}_{2} / 95 \%$ air-humidified atmosphere at 37 ${ }^{\circ} \mathrm{C}$ for $24 \mathrm{~h}$. After samples incubation, the cells were centrifuged and ressuspended in hypotonic fluorochrome solution - HFS $(50 \mu \mathrm{g} / \mathrm{mL}$ PI in $0.1 \%$ sodium citrate plus $0.1 \%$ Triton $\mathrm{X}-100)$. The samples in HFS were incubated at $4{ }^{\circ} \mathrm{C}$ during $4 \mathrm{~h}$ and immediately analyzed by flow cytometry. The PI fluorescence of 20,000 individual nuclei was measured using a FACScalibur flow cytometer. Data were analyzed by FlowJo ${ }^{\circledR}$ software (TreeStar Inc).

\section{CLONOGENIC CELL SURVIVL ASSAY}

Brief, MCF-7 and HCT-116 cells were seeded in six-well plates at density of 400 cells in $2 \mathrm{~mL}$ of medium per well. After $6 \mathrm{~h}$, cells were treated with vehicle $(0.5 \%$ DMSO $)$ and the extracts at the concentrations of $\mathrm{IC}_{50}$ or at higher concentrations of their respective $\mathrm{IC}_{90}$ values (i.e. the concentration at which cell viability was inhibited $90 \%$ ). While it is traditional to use $\mathrm{IC}_{50}$ values for comparative purposes in toxicity studies, previous studies have shown that $\mathrm{IC}_{90}$, not $\mathrm{IC}_{50}$, values are more predictive of clinically important levels of drug exposure in patients. The $\mathrm{IC}_{90}$ values for each extract-concentration curve from MTT assays was calculated as described previously (Volpe and Warren 2013). The ASL was tested at 11 and 100 $\mu \mathrm{g} / \mathrm{mL}$, both to MCF-7 and HCT-116. The ASS was evaluated against MCF-7 at concentrations of 2 and $18 \mu \mathrm{g} / \mathrm{mL}$. After $24 \mathrm{~h}$, the medium was replaced to stop the treatment and replaced by 4 $\mathrm{mL}$ by fresh medium. After 14 days, cells were stained with crystal violet and colonies up to 50 cells were counted. Plating efficiency, surviving fraction and colony mean size were determined for each condition (Franken et al. 2006).

STATISTICAL ANALYSIS

The $\mathrm{IC}_{50}$ and $\mathrm{IC}_{90}$ values for cytotoxicity activity were determined using Prism 5.0® (GraphPad Software Inc.). Data were presented as median and 95\% confidence interval. Statistical differences between the treatments and the control were evaluated by ANOVA test. Each data point represented mean $\pm \mathrm{SD}$ from at least two independent experiments performed in duplicate. Statistical differences between the treatments and the control were evaluated by ANOVA test followed by Bonferroni $(P>0.05)$.

\section{RESULTS AND DISCUSSION}

\section{UPLC-ESI-MS/MS ANALYSIS}

For better global positioning of any herbal drug, it is important to generate chemoprofiling data on the basis of maximum available number of markers for the extract (Fabri et al. 2013). For this reason, the chromatogram profiles for ASL and ASS were performed and are shown in Fig. 1 and Table I.

A. squamosa and other plants from the genus are well known by the presence of acetogenins, which have been reported as potent antimicrobial and cytotoxic compounds. Almost 30 acetogenins 
TABLE I

Compounds identified in the Annona squamosa extracts by UPLC-ESI-MS/MS analysis.

\begin{tabular}{|c|c|c|c|c|c|}
\hline \multirow[t]{2}{*}{ Compounds } & \multicolumn{2}{|c|}{ Retention time (min) } & \multirow[t]{2}{*}[\mathrm{M}+\mathrm{H}]{$^{+}(m / z)$} & \multirow[t]{2}{*}{$\begin{array}{c}\text { MS-MS ions } \\
\text { in positive ion mode }\end{array}$} & \multirow[t]{2}{*}{ References } \\
\hline & $\mathrm{ASS}^{\mathrm{a}}$ & $\mathrm{ASL}^{\mathrm{a}}$ & & & \\
\hline Anonaine & 2.98 & 2.98 & 266 & $266 \rightarrow 266$ & Da Cruz et al. 2011 \\
\hline Asimilobine & 2.30 & 2.32 & 268 & $268 \rightarrow 251,236,219,191$ & Da Cruz et al. 2011 \\
\hline Corypalmine & 2.16 & - & 342 & $342 \rightarrow 342$ & Simeón et al. 1990 \\
\hline Liriodenine & - & 3.36 & 276 & $276 \rightarrow 276$ & Da Cruz et al. 2011 \\
\hline Nornuciferine & 2.88 & 2.88 & 282 & $282 \rightarrow 282$ & Costa et al. 2010 \\
\hline Reticuline & 1.68 & 1.71 & 330 & $\begin{array}{c}330 \rightarrow 299,192,175,151 \\
143,137\end{array}$ & Costa et al. 2010 \\
\hline
\end{tabular}

${ }^{a}$ ASS - methanolic extract of Annona squamosa seeds, ASL - methanolic extract of Annona squamosa leaves; -: compound not detected.
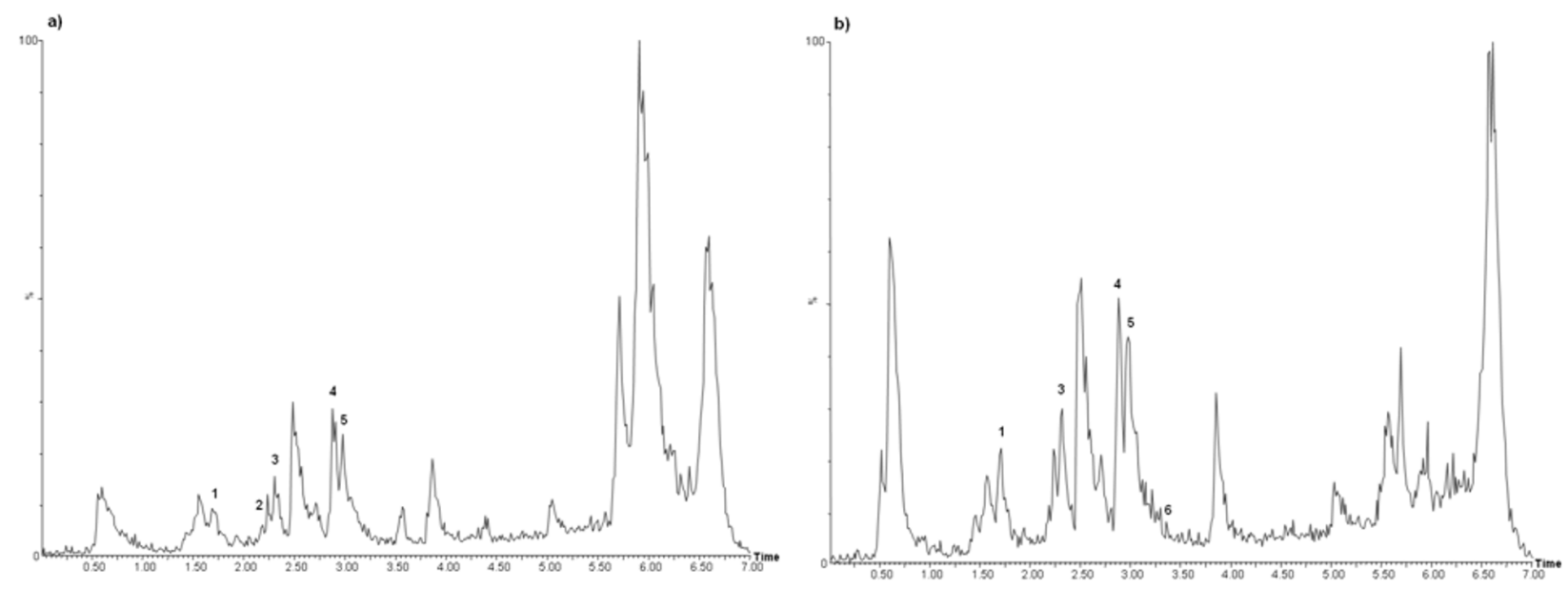

Figure 1 - Chromatograph of the methanolic extracts from Annona squamosa (a) seeds (ASS) and (b) leaves (ASL) analyzed by UPLC-ESI-MS/MS. The assignments for identified compounds (time of retention and MS/MS spectra) are based on comparisons with the corresponding isolated standards. (1) reticuline, (2) corypalmine, (3) asimilobine, (4) nornuciferine, (5) anonaine, (6) liriodenine.

were already isolated from this species (Pandey and Barve 2011). To identify other chemical constituents which could be possibly related to these activities, we investigated the alkaloid profile of ASS and ASL by UPLC-ESI-MS/MS analysis. Four alkaloids were identified in both extract as anonaine, asimilobine, nornuciferine, and reticuline. Liriodenine and corypalmine were also found in ASL and ASS, respectively (Fig. 2).

Several biological activities were already described for many of these alkaloids, which may be considered as markers for Annonaceae, as they were isolated from several species of this family
(Costa et al. 2013, Li et al. 2003, Silva et al. 2014). It is well known the cytotoxic and antimicrobial activities of anonaine (Costa et al. 2010, Li et al. 2003, Paulo et al. 1992, Villar et al. 1987), asimilobine (Costa et al. 2013, Woo et al. 1995), liriodenine (Hufford 2011, Hsieh et al. 2005, Woo et al. 1997), nornuciferine (Marti et al. 2013), and reticuline (Orhan et al. 2007, Suresh et al. 2012, Tsai et al. 1989). The mechanism of action of these compounds are not well described in the literature, however Chen et al. (2011) reported that anonaine induces DNA damage, activation of caspase 3, 7, 8 and 9, and poly ADP ribose polymerase cleavage. 
<smiles>C1=C2CCNC3Cc4ccccc4C3=C2C2=C1OCO2</smiles>

Anonaine<smiles>O=C1c2ccccc2-c2c3c(cc4ccnc1c24)OCO3</smiles>

Liriodenine<smiles>COc1c(O)cc2c3c1-c1ccccc1CC3NCC2</smiles>

Asimilobine<smiles>COc1cc2c3c(c1OC)-c1ccccc1CC3NCC2</smiles>

Nornuciferine<smiles>COc1cc2c(cc1O)CCN1Cc3c(ccc(OC)c3OC)CC21</smiles>

Corypalmine<smiles>COc1ccc(CC2c3cc(O)c(OC)cc3CCN2C)cc1O</smiles>

Reticuline

Figure 2 - Chemical structures of the compounds identified in the Annona squamosa extracts.

Thus, the chromatographic analysis strongly suggested that the compounds above mentioned may be involved in the bioactivity found for $A$. squamosa extracts.

\section{ANTIMICROBIAL ACTIVITY}

The MIC results suggested that ASL had a broad spectrum of antibacterial activity as it was effective against both Gram-negative and Gram-positive bacteria, being more active against $S$. aureus, $K$. pneumoniae and E. faecalis with MIC values of 78, 78 and $39 \mu \mathrm{g} / \mathrm{mL}$, respectively (Table II). For $S$. aureus, the MIC value was bactericidal (MBC/MIC $=1$ ), and for K. pneumoniae and E. faecalis, it was bacteriostatic $(\mathrm{MBC} / \mathrm{MIC} \neq 1$ ). ASS presented no antibacterial activity, which contradicted the results found by others studies (Rahman et al. 2005, Kotkar et al. 2011, Pandey et al. 2011).

Hospitals and other healthcare facilities are ecological environments in which various microorganisms are present interacting with each other by plasmids exchanges. This environment contributes to the emergence of microbial resistance, which is a typical example of evolution in response to a strong selective pressure (Almeida et al. 2012, Galán et al. 2013). Furthermore, the extensive and inappropriate use of antibiotics associated with the steady stream of patients and clinical staff, the increase of immunocompromised patients, the delay in diagnosis, and, in some cases, the poor hygiene conditions, favor the increased of bacterial (Guimarães et al. 2010).

In this context, Staphylococcus aureus is considered an important pathogen in human disease, as the infections caused by this agent have severe consequences, more often in hospitalized patients as it is the most common cause of infections associated with medical devices and nosocomial infections. The therapy has become a major health problem, as $S$. aureus is a strongly multiresistant micro-organism, in part due to its ability to form biofilms (Kluytmans et al. 1997, Periasamy et al. 2012). Enterococcus faecalis is also a medically important bacterium, as it is a common opportunistic pathogen in nosocomial infections, and possess a remarkable antibiotic 
TABLE II

Antibacterial activity of Annona squamosa.

\begin{tabular}{|c|c|c|c|c|c|c|c|c|}
\hline & \multicolumn{3}{|c|}{ ASL } & \multicolumn{3}{|c|}{ ASS } & \multirow{2}{*}{$\begin{array}{c}\text { Chloramphenicol } \\
\text { MIC }\end{array}$} & \multirow{2}{*}{$\begin{array}{c}\text { Ciprofloxacin } \\
\text { MIC }\end{array}$} \\
\hline & MIC & $\mathrm{MBC}$ & $\mathrm{MBC} / \mathrm{MIC}$ & MIC & $\mathrm{MBC}$ & $\mathrm{MBC} / \mathrm{MIC}$ & & \\
\hline \multicolumn{9}{|c|}{ Skin pathogen } \\
\hline $\begin{array}{c}\text { Staphylococcus } \\
\text { aureus ATCC } 6538\end{array}$ & 78 & 78 & 1 & 625 & 2500 & 4 & 12.5 & 0.39 \\
\hline \multicolumn{9}{|c|}{ Urinary pathogens } \\
\hline $\begin{array}{l}\text { Enterobacter } \\
\text { aerogenes } \\
\text { ATCC } 13048\end{array}$ & 1250 & 1250 & 1 & 5000 & $>5000$ & - & 25.0 & 0.20 \\
\hline $\begin{array}{l}\text { Enterobacter cloacae } \\
\quad \text { ATCC } 23355\end{array}$ & 625 & 625 & 1 & 2500 & $>5000$ & - & 12.5 & 0.20 \\
\hline \multicolumn{9}{|c|}{ Respiratory pathogens } \\
\hline $\begin{array}{c}\text { Klebsiella } \\
\text { pneumoniae } \\
\text { ATCC } 4552\end{array}$ & 78 & 156 & 2 & 1250 & $>5000$ & - & 12.5 & 12.5 \\
\hline $\begin{array}{c}\text { Pseudomonas } \\
\text { aeruginosa } \\
\text { ATCC } 9027\end{array}$ & 1250 & 5000 & 4 & 5000 & $>5000$ & - & 25.0 & 3.13 \\
\hline \multicolumn{9}{|c|}{ Gastrointestinal pathogens } \\
\hline $\begin{array}{l}\text { Bacillus cereus } \\
\text { ATCC } 14579\end{array}$ & 1250 & 1250 & 1 & 5000 & $>5000$ & - & 3.13 & 0.20 \\
\hline $\begin{array}{c}\text { Enterococcus faecalis } \\
\text { ATCC } 19433\end{array}$ & 39 & 78 & 2 & 313 & 5000 & 16 & 6.25 & 1.56 \\
\hline $\begin{array}{l}\text { Shigella dysenteriae } \\
\text { ATCC } 13313\end{array}$ & 625 & 625 & 1 & 2500 & $>5000$ & - & 25.0 & 0.78 \\
\hline $\begin{array}{l}\text { Escherichia coli } \\
\text { ATCC } 10536\end{array}$ & 1250 & 1250 & 1 & 5000 & $>5000$ & - & 3.13 & 0.20 \\
\hline $\begin{array}{l}\text { Salmonella } \\
\text { typhimurium } \\
\text { ATCC } 13311\end{array}$ & 1250 & 2500 & 2 & 5000 & $>5000$ & - & 1.56 & 0.20 \\
\hline $\begin{array}{l}\text { Salmonella } \\
\text { choleraesuis } \\
\text { ATCC } 10708\end{array}$ & 1250 & 5000 & 4 & 5000 & $>5000$ & - & 3.13 & 0.39 \\
\hline
\end{tabular}

$\overline{\mathrm{ASL}}$ - methanol extract of Annona squamosa leaves; ASS - methanol extract of Annona squamosa seeds; Values in $\mu \mathrm{g} / \mathrm{ml}$. (-) not calculated.

resistance, which is commonly transferred to $S$. aureus and Listeria species (Shankar et al. 2012). Klebsiella pneumoniae is the most common cause of community and hospital infections after Escherichia coli (Dong et al. 2012). This pathogen is the causative agent of $80 \%$ of the community-acquired pyogenic liver abscess, an important emerging infectious disease, in which $K$. pneumoniae strains are endowed with a hypermucoid phenotype, serum resistance, and resistance to phagocytosis (Hsieh et al. 2012).

As ASL was more effective against $S$. aureus, $K$. pneumoniae and E. faecalis, these bacteria were chosen as targets to study the ASL activity on 
established biofilms and bacterial killing. It was also evaluated whether its antibacterial action is related to membrane destabilization.

The study of microbial biofilms has received significant attention over the past decades (Dheepa et al. 2011). Biofilm is defined as an assemblage of microbial cells that is associated with a surface and enclosed in an extracellular matrix principally of polysaccharide material (Donlan 2002). Biofilmassociated organisms are fundamentally different from populations of suspended cells. The interest of researchers to study biofilms is mainly due to the fact that the ability of bacteria to form biofilms causes serious difficulties for antimicrobial therapy. Bacterial cells in biofilms are extremely resistant to treatment with antibiotics and other drugs as well as to the immune response of the host organism. Biofilms of pathogenic bacteria on medical devices, including catheters or lenses, can cause chronic infections (Bjarnsholt 2013, Plyuta et al. 2013). The importance of biofilm is well recognized in medical, environmental, and industrial contexts (Stepanovic et al. 2007).

In this context, the ability of the ASL to disrupt pre-formed biofilms of $S$. aureus, $K$. pneumoniae and $E$. faecalis was tested at the MIC, $0.5 \mathrm{MIC}$ and $0.25 \mathrm{MIC}$ (Fig. 3). Biofilm disruption at MIC and $0.5 \mathrm{MIC}$ was significantly effective for $S$. aureus and $K$. pneumoniae when compared to positive controls (Fig. 3a, b). In these concentrations, the inhibition was about $95 \%$ and $80 \%$ for $S$. aureus, $80 \%$ and $65 \%$ for $K$. pneumoniae, respectively.

The growth inhibitory action (time-kill kinetics) of ASL was tested on the same bacterial strains over a period of $24 \mathrm{~h}$, in three different concentrations (MIC, $0.5 \mathrm{MIC}$ and $0.25 \mathrm{MIC}$ values) and it was compared with the life cycle of the bacteria without the extract treatment (Fig. 4).

For $S$. aureus, all concentrations inhibited the growth cycle curve when compared with the untreated control. The bacteria showed a moderate growth in the concentration of ASL $0.125 \mathrm{MIC}$
(Fig. 4a). Similar results were also found for $E$. faecalis (Fig. 4c). The growth inhibitory action of ASL on $K$. pneumoniae was tested in a similar way, and it was observed that the bacterial life cycle was forced into the death phase since the $4^{\text {th }}$ hour of treatment. In other concentrations the bacterial growth was increased, but this growth was lower than the untreated control (Fig. 4b).

ASL exhibited rapid time dependent kinetics of the bacterial killing for both Gram negative and Gram positive bacteria, mainly at the MIC value. Antibacterial agents that display rapid kinetics of bacterial killing can potentially contain infection with greater rapidity than those that exhibit slow killing kinetics. A time-dependent bactericidal effect takes place when the concentration of the antibacterial exceeds the MIC for the microorganism while concentration-dependent bactericidal effect occurs when an antibiotic has a high concentration at the binding site for it to eliminate the micro-organism (Anantharaman et al. 2010).

Due to the variety of bacterial targets, several models for studying the mode of antibacterial action of drugs have been described in the literature. In this sense, OM permeability and nucleotide leakage were chosen to clarify the mode of action of ASL, which are associated with damages to bacterial membranes (Hao et al. 2009).

The bacterial cell wall is a rigid structure that covers the cytoplasmic membrane and gives shape to the bacteria. In the Gram-positive bacteria, the cell wall is thick consisting of several layers of peptidoglycan and surface glycopolymers as teichoic acids. In the Gram-negative bacteria, the cell wall is relatively thin and is composed of a single layer of peptidoglycan, lipoproteins, lipopolysaccharides, and OM. The OM acts as a molecular barrier that prevents the loss of intracellular proteins, and restricts the access of hydrolytic enzymes and some drugs, particularly hydrophobic antibiotics (Silva-Júnior et al. 2014). 

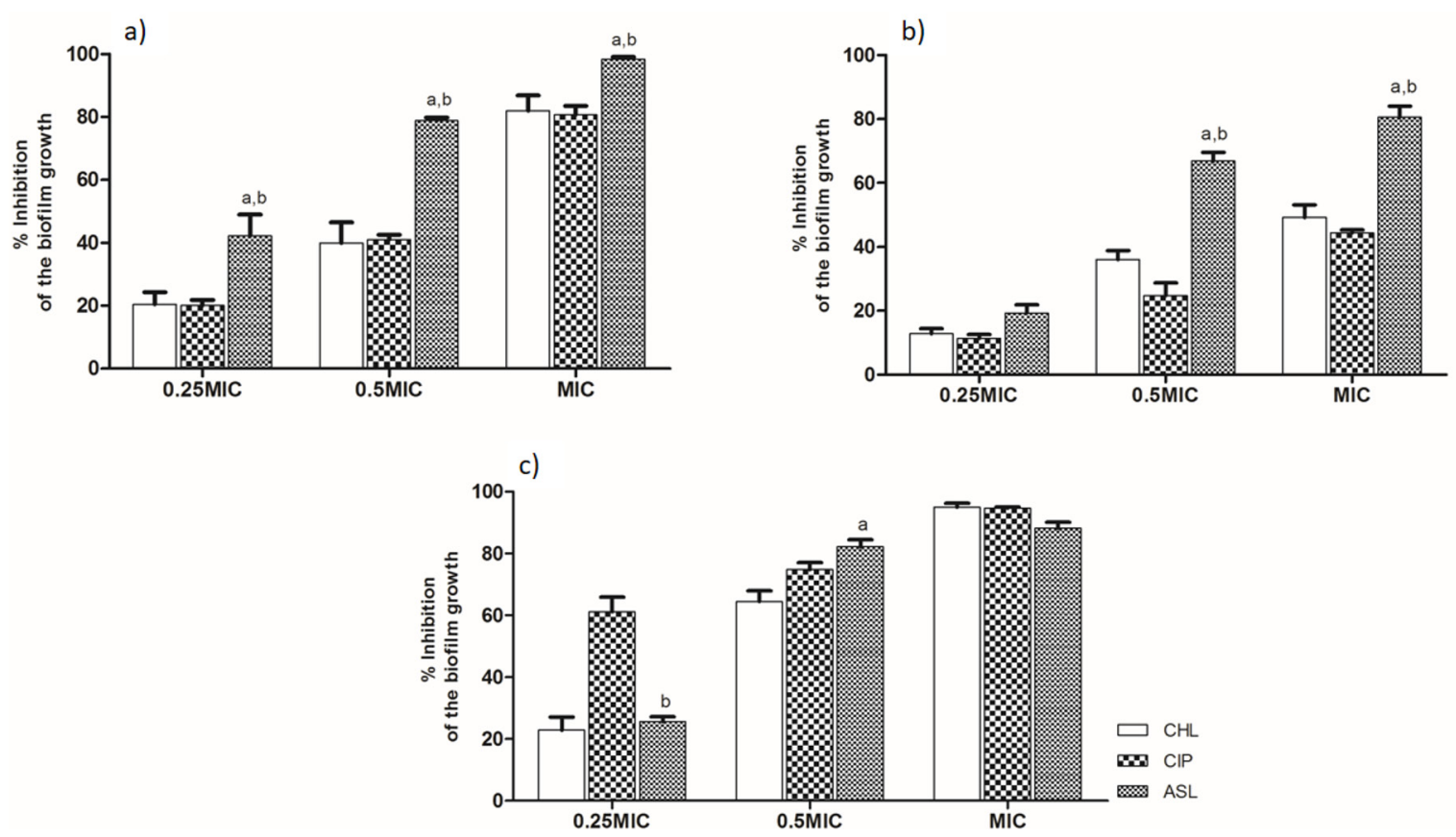

Figure 3 - The effect of methanolic extract of Annona squamosa leaves (ASL) on the established biofilms of a) S. aureus; b) K. pneumoniae and c) E. faecalis. Choramphenicol (CHL) and ciprofloxacin (CIP) were used as positive controls. Each

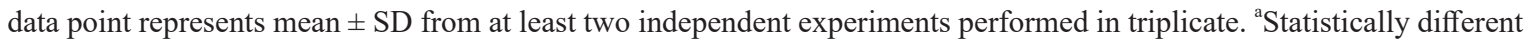
from chloramphenicol. ${ }^{\mathrm{b}}$ Statistically different from ciprofloxacin (ANOVA followed by Bonferroni, $P<0.05$ ).
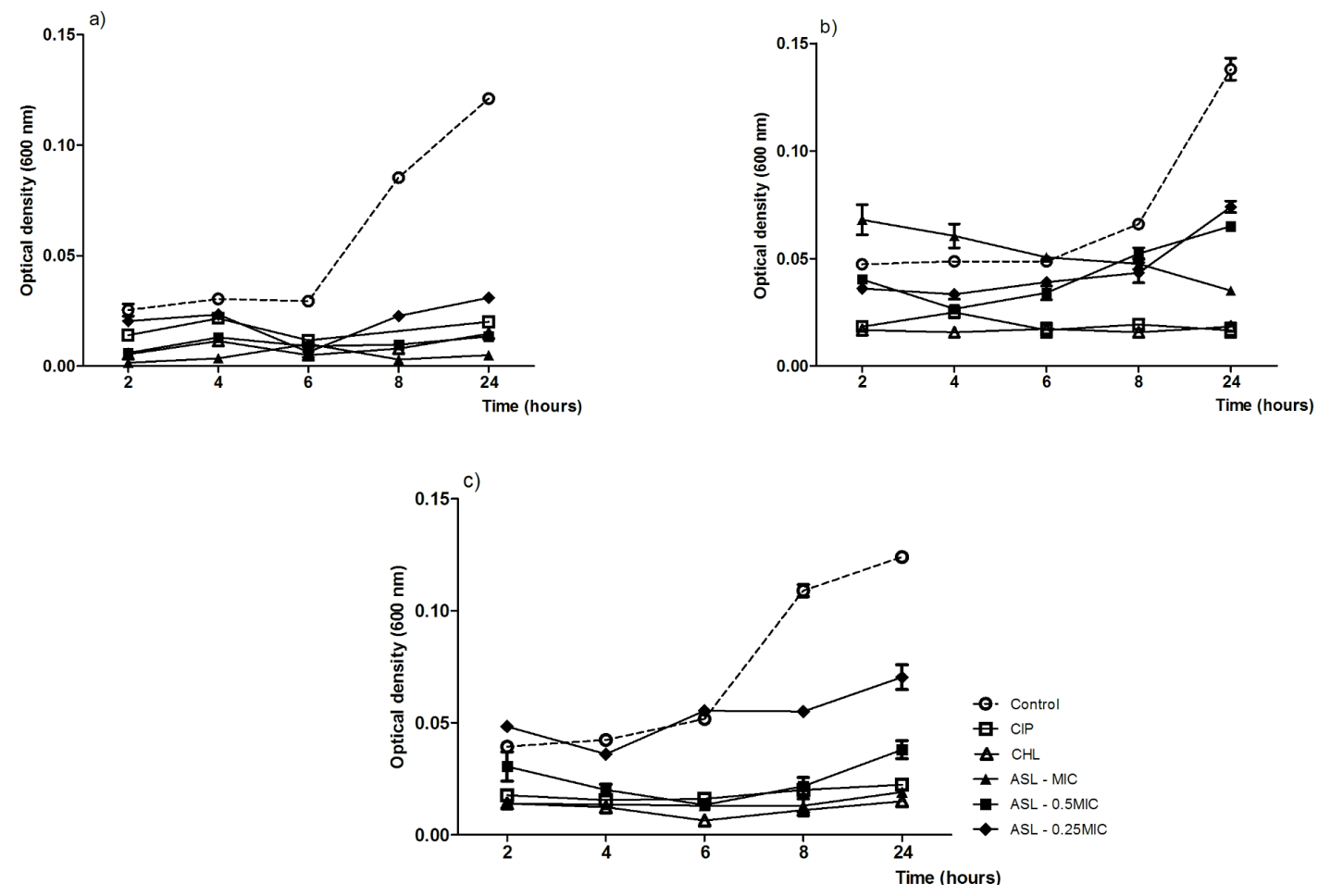

Figure 4 - Activity kinetics of methanolic extract of Annona squamosa leaves (ASL) against a) S. aureus; b) K. pneumoniae and c) E. faecalis. Choramphenicol (CHL) and ciprofloxacin (CIP) were used as positive controls. The experiments were carried out triplicate, and average values are reported. Error bars refer to the standard deviation. 
The ability of ASL to permeabilize the outer membrane of $K$. pneumoniae and $E$. faecalis was determined by a synergistic growth inhibition assay in association with hydrophobic antibiotic erythromycin. Erythromycin is typical representative of the large group of hydrophobic antibacterial agents against which the $\mathrm{OM}$ of Gram-negative cell wall is known to be an effective permeability barrier. These antibiotics do not effectively permeate the intact $\mathrm{OM}$ of Gram-negative bacteria but cross the OM of the certain OM-defective mutants as well as the OM damaged by chelators or polycations (Viljanen et al. 1990). Accordingly, this antibiotic was chosen to be probe to detect the OM permeability increase induced by ASL. The effective synergism between the hydrophobic antibiotic and ASL was evident in Fig. 5. The results indicated that ASL increased the outer membrane permeabilization in tested bacteria, exhibiting synergic effect with erythromycin.

DNA and RNA are also released and can be quantified by monitoring the absorbance at $260 \mathrm{~nm}$, as these nucleotides possess strong UV absorption at this wavelength. The nucleotide leakage test showed that cytoplasmic membrane permeability was increased by ASL, mainly against Gram-negative bacteria, which caused the efflux of nucleotides from the intracellular compartment (Fig. 6). However, it was not possible to clarify how exactly ASL interacted with the cytoplasmic membrane components and led to the leakage of nucleotides. Several possible molecular mechanisms have been proposed to explain the interaction between antibacterial drugs and the cytoplasmic membrane, including the formation of pores, solubilization of membrane proteins, and changes in the structure/function of the membrane phospholipid bilayer (Silva-Júnior et al. 2014).

Next, to confirm a bacteriostatic/bactericidal effect of ASL, we performed two additional approaches. First, the number of bacteria was quantified after staining with DAPI (Fig. 7a). Our results revealed that ASL had a significant impact on the bacterial abundance when compared to the controls, leading to a reduction in the bacterial growth of $25 \% 44 \%$ and $44 \%$ for $S$. aureus, $K$. pneumoniae and E. faecalis, respectively (Fig. 7a). This reduction is likely associated with a bacteriostatic effect of the ASL extract. Second, to assess bacterial membrane damage, we performed a quantitative analysis of viable and non-viable organisms using a fluorescent cell viability probe (Live/Dead ${ }^{\circledR}$ BacLight), which enables direct identification of loss of the plasma membrane integrity. Individual imaging of bacteria is valuable to recognize bacterial viability and their physiological functions at single-cell level (Joux and Lebaron 2000). Cells with damaged membranes are unable to maintain an electrochemical potential and are considered as dead. Our cytocentrifuge preparations enabled a clear imaging of live (green)/dead (red) bacteria in both ASL-treated and control cultures. Quantitative results showed that the ASL treatment (MIC value for 24h) of $S$. aureus, $K$. pneumoniae and E. faecalis induced an increase in the percentage of dead cells $(26 \%$, $15 \%$ and $27 \%$, respectively) compared to untreated controls (Fig. 7b, c). This bactericidal effect was also demonstrated when Baclight was used as a cell viability marker in other studies after plant-extract treatments (You et al. 2013, Abdullah et al. 2014). Altogether, these results indicate that the effect of ASL on $S$. aureus was predominantly bactericidal, with similar percentages of both dead cells $(26 \%)$ and reduced bacterial numbers $(25 \%)$, while its effect on K. pneumoniae and E. faecalis is probably both bacteriostatic and bactericidal, corroborating the data showed in table III.

\section{CYTOTOXIC ACTIVITY}

Natural products are a promising source of anticancer agents. At least $60 \%$ of anticancer drugs have natural origin, including plants, marine 
TABLE III

In vitro cytotoxicity and selectivity index of Annona squamosa extracts.

\begin{tabular}{|c|c|c|c|c|c|c|c|c|c|}
\hline \multirow{3}{*}{ Samples } & \multicolumn{9}{|c|}{ Cell lines } \\
\hline & Vero & \multicolumn{2}{|l|}{ HL60 } & \multicolumn{2}{|c|}{ Jurkat } & \multicolumn{2}{|l|}{ MCF-7 } & \multicolumn{2}{|l|}{ HCT-116 } \\
\hline & $\mathrm{IC}_{50}{ }^{\mathrm{a}}$ & $\mathrm{IC}_{50}{ }^{\mathrm{a}}$ & $\mathrm{SI}^{\mathrm{b}}$ & $\mathrm{IC}_{50}{ }^{\mathrm{a}}$ & $\mathrm{SI}^{\mathrm{b}}$ & $\mathrm{IC}_{50}{ }^{\mathrm{a}}$ & $\mathrm{SI}^{\mathrm{b}}$ & $\mathrm{IC}_{50}{ }^{\mathrm{a}}$ & $\mathrm{SI}^{\mathrm{b}}$ \\
\hline $\mathrm{ASS}^{\mathrm{c}}$ & $72.3(56.6$ - 93.9) & $5.6(2.1-14.8)$ & 12.9 & $1.1(0.1-10.2)$ & 65.7 & $2.1(0.2-16.4)$ & 34.4 & $>100$ & - \\
\hline $\mathrm{ASL}^{\mathrm{c}}$ & $43.5(11.4-166.1)$ & $4.2(2.0-9.6)$ & 10.4 & $6.4(2.2-18.7)$ & 6.8 & $11.0(5.1-23.9)$ & 4.0 & $15.2(7.4-30.9)$ & 2.8 \\
\hline Etoposide $^{\mathrm{d}}$ & $>100$ & $0.3(0.2-0.5)$ & - & $1.5(0.5-4.3)$ & - & $>100$ & - & $>100$ & - \\
\hline Doxorubicin $^{\mathrm{d}}$ & $6.4(2.7-12.1)$ & $0.6(0.2-1.5)$ & 10.7 & $0.4(0.1-4.5)$ & 16 & $0.5(0.1-9.4)$ & 12.8 & $1.8(0.4-7.9)$ & 3.6 \\
\hline
\end{tabular}

${ }^{\mathrm{a}}$ Data are presented otherwise specified as mean median and $95 \%$ confidence interval (in parentheses) of $\mathrm{IC}_{50}(\mu \mathrm{g} / \mathrm{mL}$ and $\mu \mathrm{M}$ for samples andpositive controls, respectively); ${ }^{\mathrm{b}}$ Selectivity index (SI) values were calculated using the ratio: $\mathrm{SI}=\mathrm{IC}_{50}$ non tumoral cell/IC ${ }_{50}$ cancerous cells; ${ }^{c} \mathrm{ASS}$ - methanolic extract of Annona squamosa seeds; ASL - methanolic extract of Annona squamosa leaves; ${ }^{\mathrm{d}}$ Positive controls; (-) not tested.
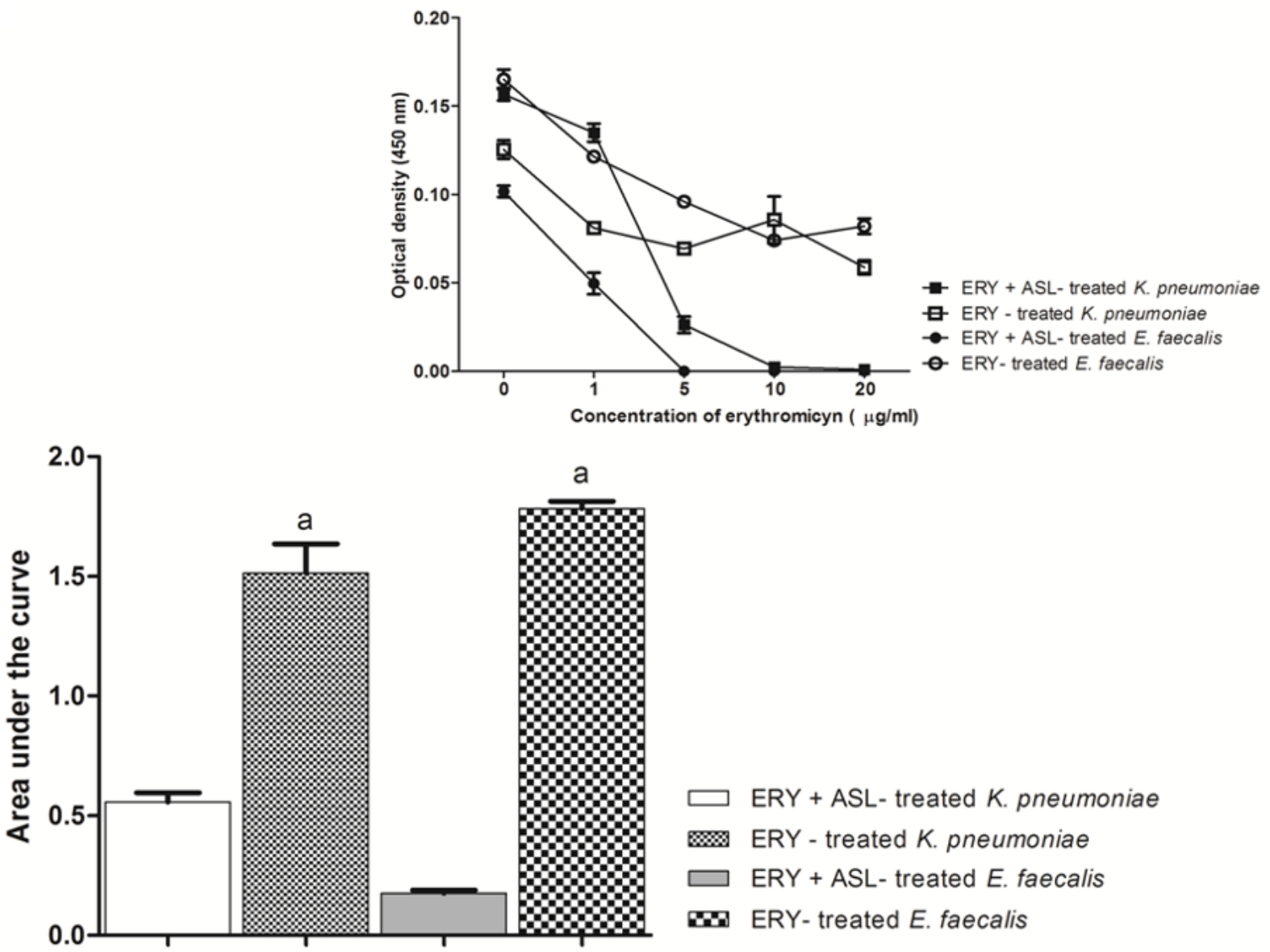

Figure 5 - Mode of action of methanolic extract of Annona squamosa leaves (ASL). Outer membrane permeability of K. pneumoniae

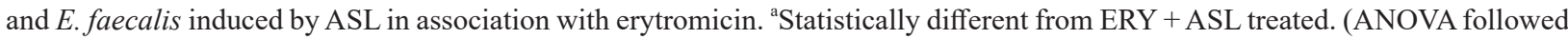
by Bonferroni, $P<0.05)$. All experiments were carried out in triplicate, and average values are reported. Error bars refer to the standard deviation. 


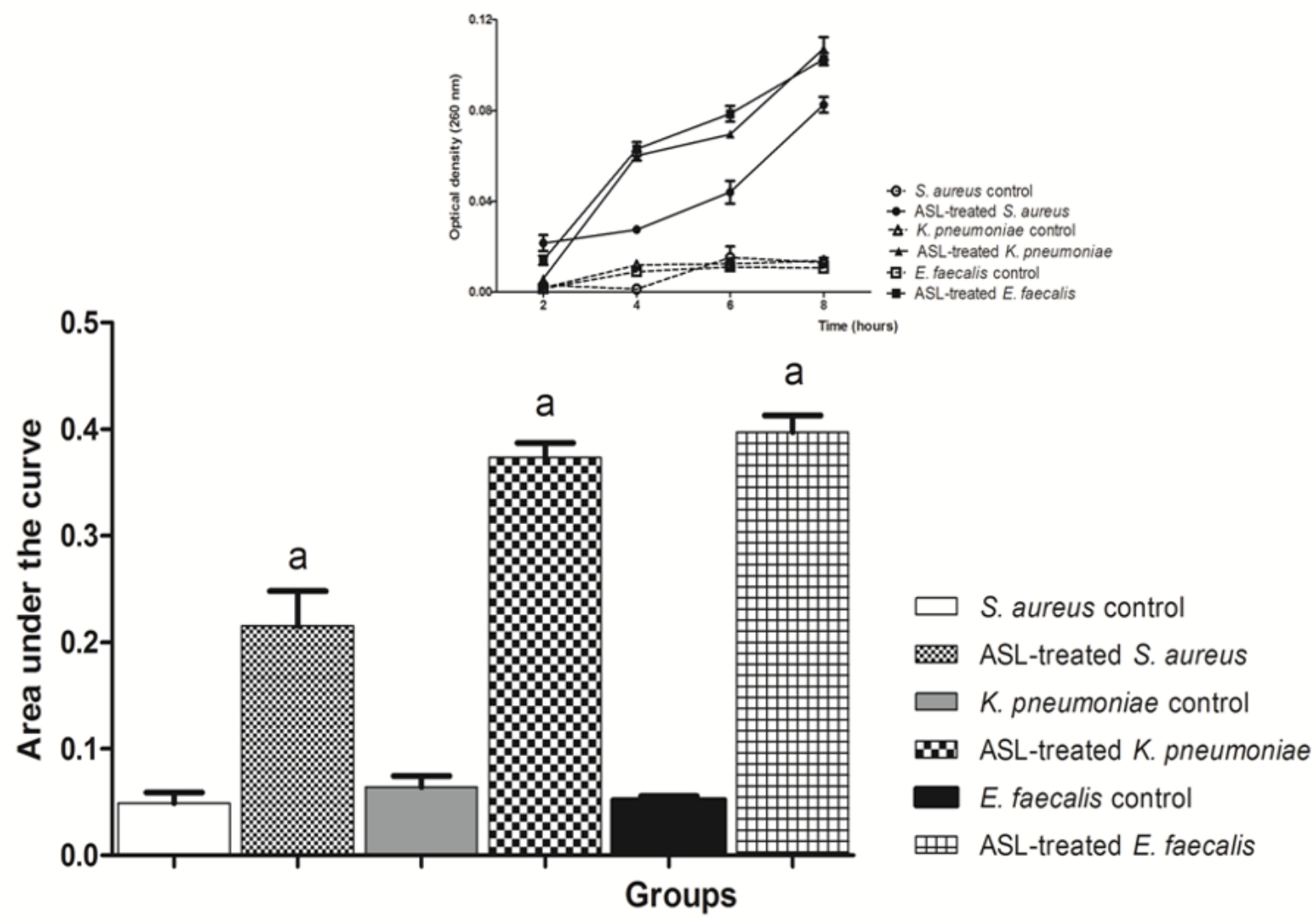

Figure 6 - Mode of action of methanolic extract of Annona squamosa leaves (ASL). Effect of ASL on the amount of the total

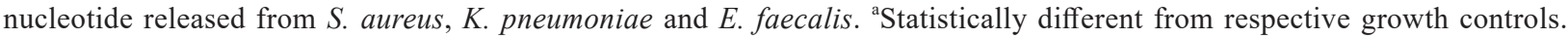
${ }^{b}$ Statistically different from ASL-treated $S$. aureus (ANOVA followed by Bonferroni, $P<0.05$ ). All experiments were carried out in triplicate, and average values are reported. Error bars refer to the standard deviation.

organisms and microorganisms (Newman and Cragg 2012, Brandão et al. 2010, Mendes et al. 2010).

In this study, it was evaluated the antiproliferative potential of ASS and ASL by MTT assay against non-tumor (VERO), leukemia (Jurkat and HL60), breast cancer (MCF-7), and colorectal cancer (HCT-116) cell lines (Table III). The results showed that ASS was more active against Jurkat and MCF-7 cells, with $\mathrm{CI}_{50} 1.1$ and $2.1 \mu \mathrm{g} / \mathrm{mL}$, respectively. ASL showed promising activity against Jurkat and HL60, with $\mathrm{CI}_{50}$ 6.4. and 4.2 $\mu \mathrm{g} / \mathrm{mL}$, respectively. Both extracts showed lower activity against VERO cells (Table III).

The selectivity index (SI) indicates the selective effects of the extracts against cancer cells versus non-tumor cells (Prayong et al. 2008). The SI values lower than 2 indicate general toxicity of the pure compound (Syarifah et al. 2011). According to the Table III, both extracts showed high selectivity with SI > 3, except for ASS against HCT-116, which is inactive against this lineage (Mahavorasirikul et al. 2010). ASS was more selective than ASL for HL60, Jurkat and MCF-7 cells, being most significant and promising for Jurkat and MCF-7 with SI of 65.7 and 34.4, respectively. Syarifah et al. (2011) report that plant extracts with selectivity index higher than 3 can be considered as selective. Therefore, ASS and ASL presented reasonable selectivity and are very promissory as source of new anticancer compounds. 

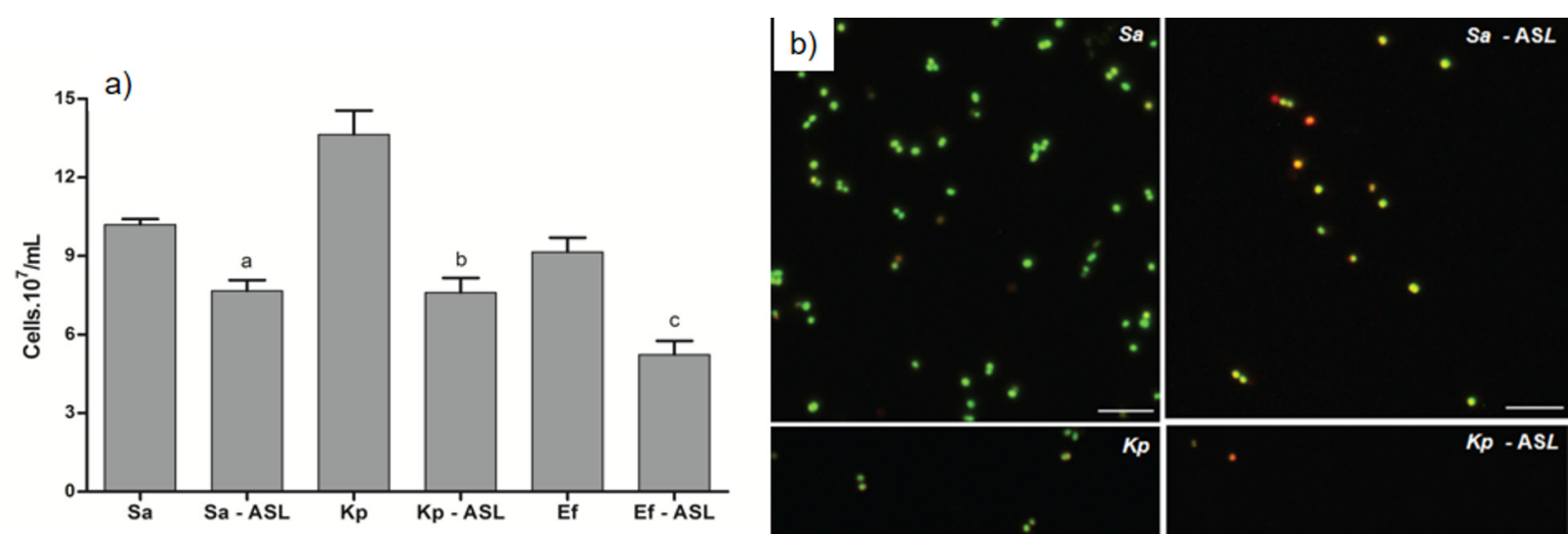

c)
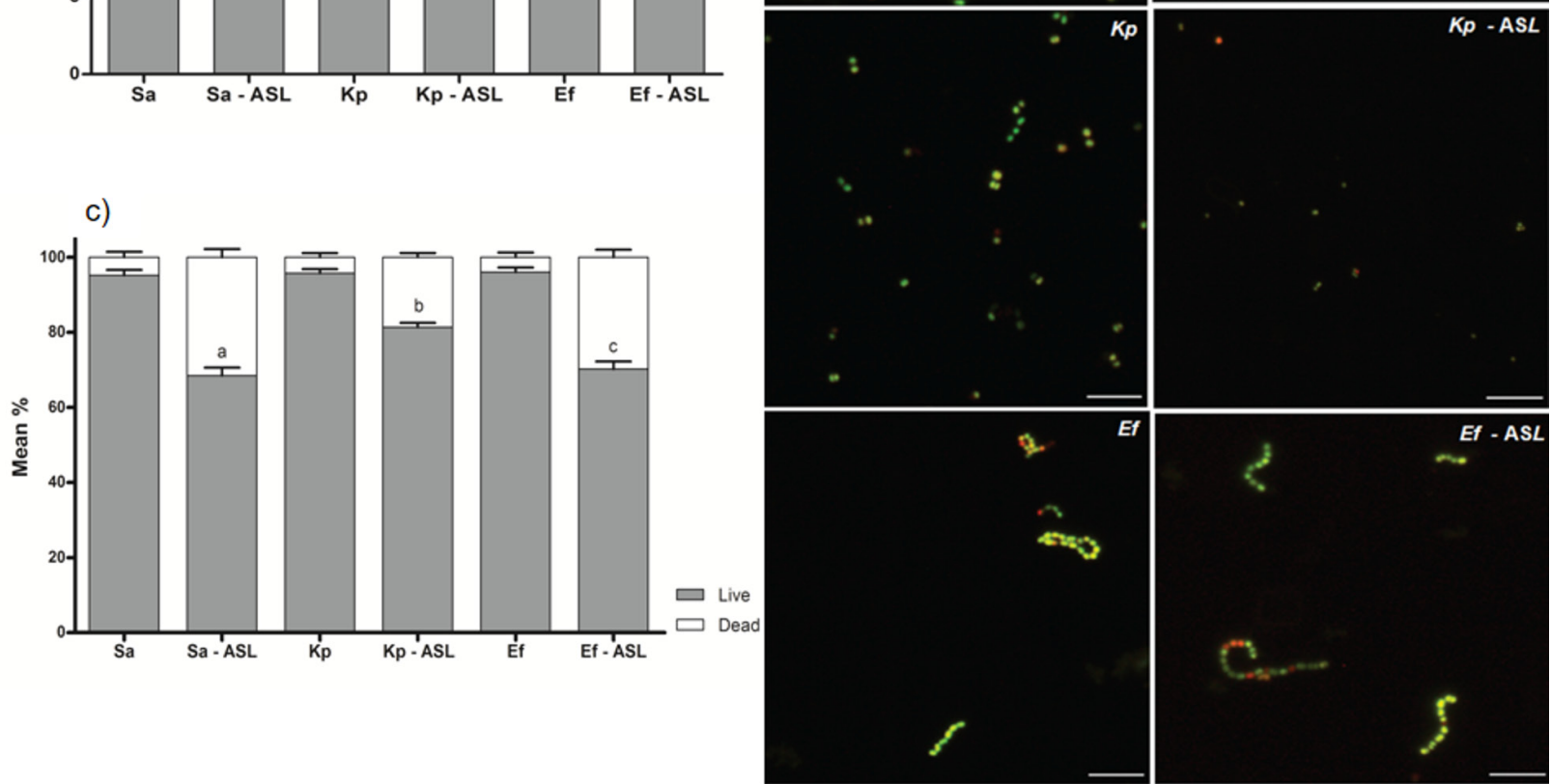

Figure 7 - Effect of methanolic extract of Annona squamosa leaves (ASL) on bacterial growth of S. aureus, K. pneumoniae and E. faecalis. a) Bacteria density evaluated after staining with DAPI. b) Live/dead bacteria were clearly observed as green or red

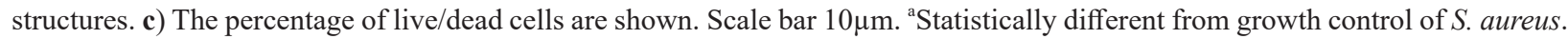

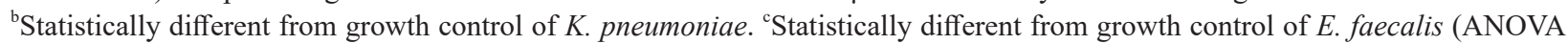
followed by Bonferroni, $P<0.05$ ). All experiments were carried out in triplicate, and average values are reported. Error bars refer to the standard deviation.

Cancer, which includes the colorectal cancer and the promyelocytic leukemia, is a relevant public health problem, so the investments to prevent and perform early detection of this disease, and to identify new chemotherapeutic agents that are capable to increase the patients survival, are strongly required (Siegel et al. 2015). Leukemia is a malignant neoplasm characterized by abnormal differentiation of myelocytic cells, and it is associated with a hemorrhagic syndrome (Prevedello and Sagrillo 2008). The survival of patients with leukemia, generally, is influenced by the patient possibilities to buy or have access to the medications, which contributes to the considerable variations in development and non development countries (Quaglia et al. 2013). The cytotoxic activity of $A$. squamosa reported in this study and the lack of activity against VERO cells may be relevant in the search of new anticancer therapeutic tools, especially those with minor adverse effects caused by the cytotoxicity for non-tumor cells.

Many chemotherapeutic strategies interfere with important steps in cell cycle progression, such as DNA replication and repair. They may act as DNA polymerase inhibitors, topoisomerase inhibitors, or DNA alkylating agents preventing 

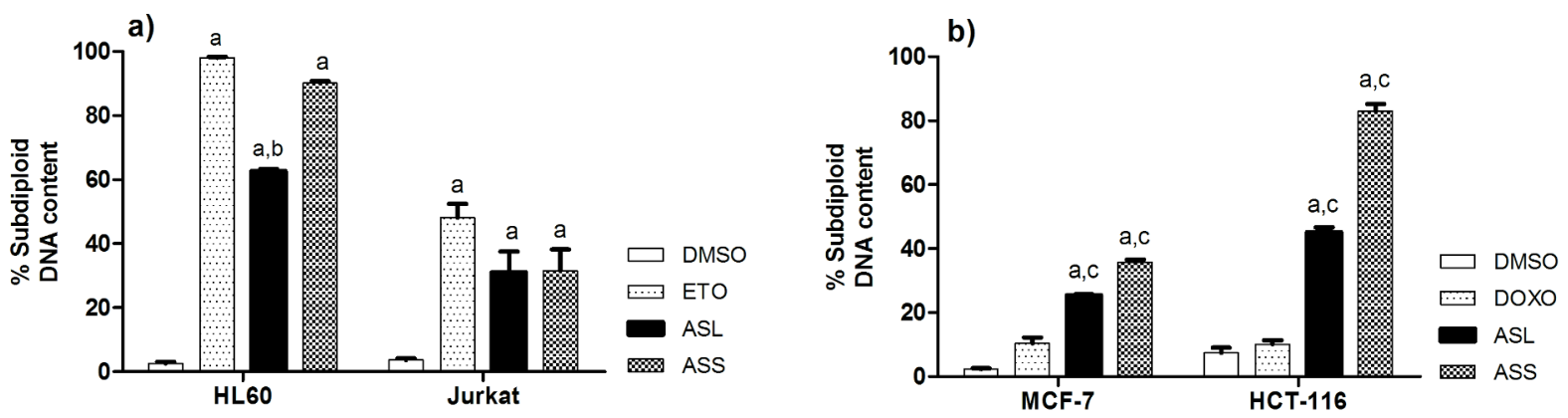

Figure 8 - Effect of methanolic extracts of Annona squamosa seeds (ASS) and leaves (ASL) on DNA content of tumor cell lines. HL-60, Jurkat, MCF-7 and HCT-116 cells were incubated with samples $(20 \mu \mathrm{g} / \mathrm{mL})$ or with control $(0.5 \%$ DMSO) for $24 \mathrm{~h}$. DNA content was assayed by PI stain and flow cytometry analysis. A) Etoposide (ETO - $8 \mu \mathrm{g} / \mathrm{mL}$ ) and B) doxorubicin (DOXO - 5 $\mu \mathrm{g} / \mathrm{mL}$ ), positive controls are demonstrated. Each data point represents mean $\pm \mathrm{SD}$ from at least two independent experiments performed in duplicate. ${ }^{\mathrm{a} S t a t i s t i c a l l y ~ d i f f e r e n t ~ f r o m ~ n e g a t i v e ~ c o n t r o l ~}(0.5 \% \mathrm{DMSO}) .{ }^{\mathrm{b}}$ Statistically different from positive control (etoposide) ${ }^{\mathrm{c}}$ Statistically different from positive control (doxorrubicin) (ANOVA followed by Bonferroni, $P<0.05$ ).

cancer progression and inducing apoptosis as a secondary effect ( $\mathrm{Li}$ et al. 2003). For this reason, it was also investigated if the cytotoxic effects found for ASL and ASS were associated with their potential to induce cell death by apoptosis. The method described by Ricardi and Nicolleti (2006) is based on the principle that the apoptotic cells, among other typical features, are characterized by DNA fragmentation and, consequently, by the loss of nuclear DNA content. Apoptotic nuclei appear as a broad hypodiploid DNA peak which was easily distinguished from the narrow cluster of cells with normal (diploid) DNA content. This simple and reproducible method should prove useful for assessing the apoptosis of specific cell populations in heterogeneous tissues.

The results clearly demonstrated that ASS and ASL induced an increase of subdiploid DNA content (DNA fragmentation) in all cells when compared to the control $(0.5 \%$ DMSO $)$, which suggested that these compounds activated the apoptosis pathway. This cytotoxic effect was more significant for HL60 and HCT-116 cell lines, when compared to the reference drugs (Fig. 8).

The clonogenic assay has been used to detect cells that have retained the capacity for producing a large number of progeny after treatments that can cause cell reproductive death as a result of damage to chromosomes and apoptosis (Afef et al. 2013). Moreover, the clonogenic assay is commonly used for monitoring the efficacy and for determining the effects of cytotoxic agents and other anti-cancer therapeutics on colony forming ability, in different cell lines (Rafehi et al. 2011). For clonogenic assays, two concentrations of extracts were evaluated $\left(\mathrm{IC}_{50}\right.$ and $\mathrm{IC}_{90}$ ) using two susceptible lineages (MCF-7 and HCT-116). The results (Fig. 9), showed that both extracts totally reduced the clonogenic survival at higher concentrations $\left(\mathrm{IC}_{90}\right)$ to the two lineages in comparison with untreated control (0.5\% DMSO), which was taken as 100 percent colony forming ability. ASS presented the best efficacy to decrease colony forming ability comparing with ASL against MCF-7 cells. ASS reduced almost all colonies at 18 $\mu \mathrm{g} / \mathrm{mL}\left(\mathrm{IC}_{90}\right.$ value). This same effect was observed for ASL only at $100 \mu \mathrm{g} / \mathrm{mL}$ (concentration 5.5 times smaller). Moreover, ASL demonstrated similar effect against HCT-116 cells and MCF-7 at $11 \mu \mathrm{g} /$ $\mathrm{mL}$ (at $\mathrm{IC}_{50}$ values).

\section{CONCLUSIONS}

This study corroborates to the ethnopharmacological uses of Annona squamosa, and reinforced that this plant presents a remarkable phytomedicinal 
ASS

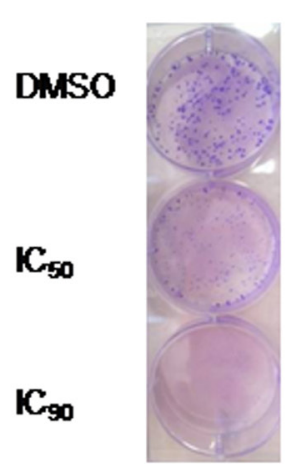

MCF-7

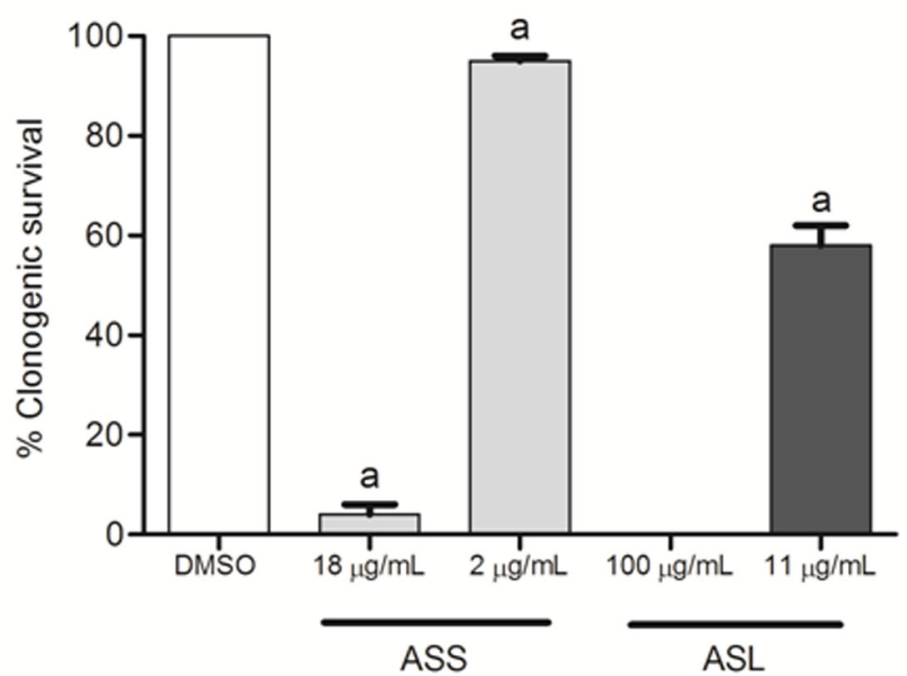

ASL

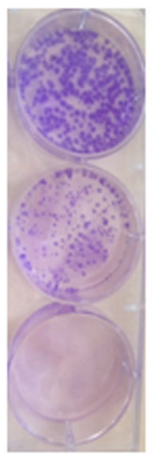

HCT-116

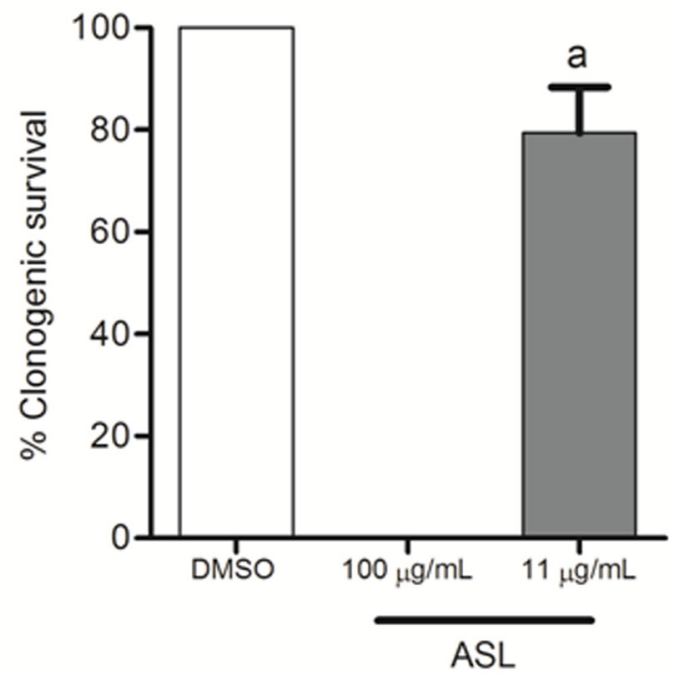

Figure 9 - Effects of methanolic extracts of Annona squamosa seeds (ASS) and leaves (ASL) on clonogenic survival of MCF-7 and HCT-116 cells. The lineages were seed at density of $4 \times 10^{3}$ cell/well and treated with the extracts at their $\mathrm{IC}_{90}$ and $\mathrm{IC}_{50}$ concentrations or control $(0.5 \%$ DMSO) for 24 hours. Medium was replaced by fresh complete medium and cultured for 14 days. The fraction of

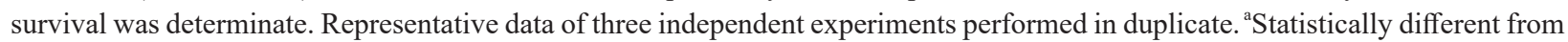
negative control $(0.5 \%$ DMSO) (ANOVA followed by Bonferroni, $P<0.05$ ).

potential, especially in terms of antitumor and antimicrobial activities. Besides, the further investigation on its antimicrobial activity revealed that the mechanism of action of the chemical constituents of the leaves is related to bacterial membranedestabilization induction. It is noteworthy to mention that $A$. squamosa is commonly used as food, which supports further studies to evaluate whether the ingestion of this plant may be useful to prevent cancer development or bacterial infections. Some compounds with cytotoxic and antimicrobial activities documented in the literature were detected in the bioactive samples of $A$. squamosa, such as anonaine, asimilobine, lirioderine, nornuciferine and reticuline. However, further investigations (in vitro and in vivo) are necessary to understand the toxicity and efficacy toward a clinical employment of A. squamosa extracts or isolated compounds.

\section{ACKNOWLEDGMENTS}

The authors are grateful to the Fundação de Amparo à Pesquisa do Estado de Minas Gerais (FAPEMIG), to the Fundação de Amparo à Pesquisa do Estado 
de São Paulo (FAPESP), Conselho Nacional de Desenvolvimento Científico e Tecnológico (CNPq) and the Universidade Federal de Juiz de Fora (UFJF)/ Brazil for financial support, and also to Dr. Luciana Moreira Chedier from the Departamento de Botânica/ UFJF for the botanical identification of the species.

\section{REFERENCES}

ABDULLAH S, GOBILIK J AND KHIM-PHIN C. 2014. In vitro antimicrobial mode of action of Cynodon dactylon (L.) Pers. solid phase extract (SPE) against selected pathogens. International Conference on Civil, CBEE, Istanbul, Turkey, p. 27-28.

AFEF D, MONIA D AND ABDERRAHMAN B. 2013. Evaluation of the antiproliferative activity of methanol extract and its fractions from fhe mediterranean seaweed, Halurus equisetifolius. Int J of Pharm Pharm Sci 5(3): 148152.

ALMEIDA AA, MANFRÉ LLM, GARCIA MTRC, CHANG MR AND OLIVEIRA KMP. 2012. Fatores associados a bacteremia por Klebsiella spp. em hospital universitário. Evidência-Ciência e Biotecnologia 12(2): 165-174.

ALMEIDA VL, LEITAO A, REINA LDCB, MONTANARI CA, DONICCI CL AND LOPES MTP. 2005. Câncer e agentes antineoplásicos ciclo-celular específicos e ciclocelular não específicos que interagem com o DNA: uma introdução. Quim Nova 28(1): 118-129.

ANANTHARAMAN A, RIZVI MS AND SAHAL D. 2010. Synergy with rifampin and kanamycin enhances potency, kill kinetics, and selectivity of de novo-designed antimicrobial peptides. Antimicrob Agents Chemother 54(5): 1693-1699.

BJARNSHOLT T. 2013. The role of bacterial biofilms in chronic infections. Acta Pathol Microbiol Immunol Scand 121(136): 1-51.

BOULOS L, PREVOST M, BARBEAU B, COALLIER J AND DESJARDINS R. 1999. LIVE/DEAD_BacLight: application of a new rapid staining method for direct enumeration of viable and total bacteria in drinking water. J Microbiol Methods 37: 77-86.

BRANDÃO HN, DAVID JP, COUTO RD, NASCIMENTO JAP AND DAVID JM. 2010. Química e farmacologia de quimioterápicos antineoplásicos derivados de plantas. Quim Nova 33(6): 359-369.

BRASIL. 2006. Ministério da Saúde. Secretaria de Ciência, Tecnologia e Insumos Estratégicos. Departamento de Assistência Farmacêutica. Política nacional de plantas medicinais e fitoterápicos.
CHEN BH, CHANG HW, HUANG HM, CHONG IW, CHEN JS, CHEN CY AND WANG HM. 2011. (-)-Anonaine induces DNA damage and inhibits growth and migration of human lung carcinoma H1299 Cells. J Agric Food Chem 59(6): 2284-2290.

CLINICAL AND LABORATORY STANDARDS INSTITUTE. 2010. Performance standards for antimicrobial susceptibility testing; Twenty first informational supplement. CLSI Document M100-S21.

COSTA EV, CRUZ PEO, LOURENÇO CC, MORAES VRS, NOGUEIRA PCL AND SALVADOR MJ. 2013. Antioxidant and antimicrobial activities of aporphinoids and other alkaloids from the bark of Annona salzmannii A. DC. (Annonaceae). Nat Prod Res 27(11): 1002-1006.

COSTA EV, PINHEIRO MLB, BARISON A, CAMPOS FR, SALVADOR MJ, MAIA BHLNS, CABRAL EC AND EBERLIN MN. 2010. Alkaloids from the barks of Guatteria hispida and their evaluation as antioxidant and antimicrobial agents. J Nat Prod 73: 180-183.

COUTINHO MR, QUADRI MB, MOREIRA RFPM AND QUADRI MGN. 2004. Partial purification of anthocyanins from Brassica oleracea (red cabbage). Separ Sci Technol 39(16): 3769-3782.

DA CRUZ PEO, COSTA EV, MORAES VRS, NOGUEIRA PCL, VENDRAMIN ME, BARISON A, FERREIRA AG AND PRATA APN. 2011. Chemical constituents from the bark of Annona salzmannii (Annonaceae). Biochem Syst Ecol 39: 872-875.

DATTA A, GHOSHDATIDAR S AND SINGH M. 2011. Antimicrobial Property of Piper betel Leaf against Clinical Isolates of Bacteria. Int J Pharm Sci Res 2(3): 104-109.

DHEEPA M, RASHME VL AND APPALARAJU B. 2011. Comparison of biofilm production and multiple drug resistance in clinical isolates of Acinetobacter baumanii from a tertiary care hospital in South India. Int $\mathrm{J}$ PharmBiomed Sci 2(4): 103-107.

DONG F, WANG B, ZHANG L, TANG H, LI J AND WANG Y. 2012. Metabolic Response to Klebsiella pneumoniae Infection in an Experimental Rat Model. PLoS ONE 7(11): e51060.

DONLAN RM. 2002. Biofilms: microbial life on surfaces. Emerg Infect Dis 8: 881-890.

FABRI RL, GARCIA RA, FLORÊNCIO JR, PINTO NCC, OLIVEIRA LG, AGUIAR JAK, RIBEIRO A AND SCIO E. 2013. Anti-inflammatory and antioxidative effects of the methanolic extract of the aerial parts of Mitracarpus frigidus in established animal models. J Pharm Pharmacol 66(5): 722-732.

FOUQUE A. 1972. Especies frutieres da Amerique Tropicale. Fruits 27(1): 62-67.

FRANKEN NA, RODERMOND HM, STAP J, HAVEMAN J AND VAN BREE C. 2006. Clonogenic assay of cells in vitro. Nat Protoc 1: 2315-2319. 
FREESE HM, KARSTEN U AND SCHUMANN R. 2006. Bacterial abundance, activity, and viability in the eutrophic River Warnow, northeast Germany. Microb Ecol 51(1): 117-127.

GALÁN JC, GONZÁLEZ-CANDELAS F, ROLAIN JM AND CANTÓN R. 2013. Antibiotics as selectors and accelerators of diversity in the mechanisms of resistance: from the resistome to genetic plasticity in the $\beta$-lactamases world. Front Microbiol 4(9): 1-11.

GUIMARÃES DO, MOMESSO LS AND PUPO MT. 2010. Antibióticos: importância terapêutica e perspectivas para a descoberta e desenvolvimento de novos agentes. Quim Nova 33(3): 667-679.

GUPTA RK, KESARI AN, WATAL G, MURTHY PS, CHANDRA R AND TANDON V. 2005. Nutritional and hypoglycemic effect of fruit pulp of Annona squamosa in normal healthy and alloxan-induced diabetic rabbits. Ann Nutr Metab 49: 407-413.

GURIB-FAKIM A. 2006. Medicinal plants: traditions of yesterday and drugs of tomorrow. Mol Aspects Med 27: $1-93$.

HAO G, SHI Y-H, TANG Y-L AND LE G-W. 2009. The membrane action mechanism of analogs of the antimicrobial peptide Buforin 2. Peptides 30: 1421-1427.

HSIEH PF, LIN TL, YANG FL, WU MC, PAN YJ, WU SH AND WANG JT. 2012. Lipopolysaccharide O1 antigen contributes to the virulence in Klebsiella pneumoniae causing pyogenic liver abscess. PLoS ONE 7(3): e33155.

HSIEH TJ, LIU TZ, CHERN CL, TSAO DA, LU FJ, SYU YH, HSIEH PY, HU HS, CHANG TT AND CHEN CH. 2005. Liriodenine inhibits the proliferation of human hepatoma cell lines by blocking cell cycle progression and nitric oxide-mediated activation of p53 expression. Food Chem Toxicol 43(7): 1117-1126.

HUFFORD CD. 2011. Antibacterial and antifungal activity of liriodenine and related oxoaporphine alkaloids. J Pharm Sci 69(10): 1180-1183.

JEMAL A, SIEGEL R, XU J AND WARD E. 2011. Global cancer statistics. CA: Cancer J Clin 61: 69-90.

JOLY AB. 1979. Botânica, introdução à taxonomia vegetal, $3^{\text {a }}$ ed., São Paulo: Companhia Nacional, 777 p.

JOUX F AND LEBARON P. 2000. Use of fluorescent probes to assess physiological functions of bacteria at single-cell level. Microbes Infect 2: 1523-1535.

KLUYTMANS J, VAN BELKUM A AND VERBRUGH H. 1997. Nasal carriage of Staphylococcus aureus: epidemiology, underlying mechanisms, and associated risks. Clin Microbiol Rev 10(3): 505.

KOTKAR HM, MENDKI PS, SADAN SVGS, JHA S, UPASANI SM AND MAHESHWARI VL. 2002. Antimicrobial and pesticidal activity of partially purified flavonoids of Annona squamosa. Pest Manag Sci 58: 33-37.
KUETE V. 2010. Potential of Cameroonian plants and derived products against microbial infections: a review. Planta Med 76: 1479-1491.

LI HT, WU HM, CHEN HL, LIU CM AND CHEN CY. 2003. The pharmacological activities of (-)-anonaine. Molecules 18: 8257-8263.

LORENZI H AND MATOS FJA. 2002. Plantas Medicinais do Brasil - Nativas e Exóticas, 2a ed., São Paulo: Plantarum, $544 \mathrm{p}$.

MAHAVORASIRIKUL W, VIYANANT V, CHAIJAROENKUL W, ITHARAT A AND NABANGCHANG K. 2010. Cytotoxic activity of Thai medicinal plants against human cholangiocarcinoma, laryngeal and hepatocarcinoma cells in vitro. BMC Complement Alternat Med 10(55): 1-8.

MARTI G ET AL. 2013. Natural aristolactams and aporphine alkaloids as inhibitors of CDK1/Cyclin B and DYRK1A. Molecules 18: 3018-3027.

MENDES E, HERDEIRO MT AND PIMENTEL F. 2010. $\mathrm{O}$ uso de terapêuticas à base de plantas por doentes oncológicos. Acta Med Port 23(5): 901-908.

MONKS A, SCUDIERO D, SKEHAN P, SHOEMAKER R, PAULL K, VISTICA D, HOSE C, LANGLEY J, CRONISE P AND VAIGRO-WOLFF A. 1991. Feasibility of a high-flux anticancer drug screen using a diverse panel of cultured human tumor cell lines. J Natl Cancer Inst 83(11): 757-766.

NEWMAN DJ AND CRAGG GM. 2012. Natural products as sources of new drugs over the 30 years from 1981 to 2010 . J Nat Prod 75(3): 311-335.

NOSTRO A, ROCCARO AS, BISIGNANO G, MARINO A, CANNATELLI MA, PIZZIMENTI FC, CIONI PL, PROCOPIO F AND BLANCO AR. 2007. Effects of oregano, carvacrol and thymol on Staphylococcus aureus and Staphylococcus epidermidis biofilms. J Med Microbiol 56(5): 519-523.

OLIVEIRA MJR, SIMÕES MJS AND SASSI CRR. 2004. Fitoterapia no Sistema de Saúde Pública (SUS) no estado de São Paulo, Brasil. Rev Bras Plantas Med 8(2): 39-41.

ORHAN I, ÖZÇELIK B, KARAOĞLU T AND ŞENER B. 2007. Antiviral and antimicrobial profiles of selected isoquinoline alkaloids from Fumaria and Corydalis species. Z Naturforsch C A 62(12): 19-26.

PADUA MS, MENDES-COSTA MC, FERREIRA JMS, MAGALHÃES JC AND CASTRO AHF. 2013. Assessment of antimicrobial activity in vitro of ethanolic extracts of Banisteriopsis anisandra (A. Juss.) B. Gates (Malpighiaceae). Rev Bras Plantas Med 15(3): 431-437.

PANDEY N AND BARVE D. 2011. Phytochemical and pharmacological review on Annona squamosa Linn. Int J Res Pharm Biol Sci 2(4): 1404-1412.

PAULO MQ, BARBOSA-FILHO JM, LIMA EO, MAIA RF, BARBOSA RC AND KAPLAN MA. 1992. Antimicrobial 
activity of benzylisoquinoline alkaloids from Annona salzmanii D.C. J Ethnopharmacol 36(1): 39-41.

PERIASAMY S, JOO HS, DUONG AC, BACH THL, TON VY, CHATTERJEE SS, CHEUNG GYC AND OTTO M. 2012. How Staphylococcus aureus biofilms develop their characteristic structure. Proc Natl Acad Sci USA 109(4): 1281-1286.

PLYUTA V, ZAITSEVA J, LOBAKOVA E, ZAGOSKINA N, KUZNETSOV A AND KHMEL I. 2013. Effect of plant phenolic compounds on biofilm formation by Pseudomonas aeruginosa. Acta Pathol Microbiol Immunol Scand 121(11): 1073-1081.

PRAYONG P, BARUSRUX S AND WEERAPREEYAKUL N. 2008. Cytotoxic activity screening of some indigenous Thai plants. Fitoterapia 79: 598-601.

PREVEDELLO CP AND SAGRILLO MR. 2008. Leucemia promielocítica aguda. Disc Scientia Série: Ciências da Saúde 9(1): 39-50.

QUAGLIA A, LILLINI R, MAMO C, IVALDI E, VERCELLI M AND SEIH (SOCIO-ECONOMIC INDICATORS, HEALTH) WORKING GROUP. 2013. Socio-economic inequalities: a review of methodological issues and the relationships with cancer survival. Crit Rev Oncol Hemat 85(3): 266-277.

RAFEHI H, ORLOWSKI C, GEORGIADIS GT, VERVERIS K, EL-OSTA A AND KARAGIANNIS TC. 2011. Clonogenic assay: adherent cells. J Vis Exp 13(49): 2573.

RAHMAN MM, PARVIN S, HAQUE ME, ISLAM ME AND MOSADDIK MA. 2005. Antimicrobial and cytotoxic constituents from the seeds of Annona squamosa. Fitoterapia 76(5): 484-489.

RICARDI C AND NICOLETTI I. 2006. Analysis of apoptosis by propidium iodide staining and flow cytometry. Nat Protoc 1: 1458-1461.

RIESER MJ, FANG XP, ANDERSON JE, MIESBAUER LR, SMITH DC AND MACLAUGHLIN JL. 2004. Muricatetrocins A and B and gingantetrocin B: three new cytotoxic monohydrofuran-ring acetogenins from Annona muricata. Med Biol Chem 76(6): 2433-2444.

ROSA C, CÂMARA SG AND BÉRIA JU. 2011. Representações e intenções de uso da fitoterapia na atenção básica à saúde. Ciên Saúde Colet 16(1): 311-318.

ROSSI F. 2011. The challenges of antimicrobial resistance in Brazil. Clin Infect Dis 52(9): 1138-1143.

SHANKAR J, WALKER RG, WARD D AND HORSBURGH MJ. 2012. The Enterococcus faecalis exoproteome: identification and temporal regulation by Fsr. PLoS ONE 7(3): e33450.

SHARMA H AND KUMAR A. 2011. Etnobotanical studies on medicinal plants of Rajasthan (India): a review. J Med Plant Res 5(7): 1107-1112.

SIEGEL RL, MILLER KD AND JEMAL A. 2015. Cancer Statistics. CA Cancer J Clin 65(1): 5-29.
SILVA FM, SOUZA AD, KOOLEN HH, BARISON A, VENDRAMIN ME, COSTA EV, FERREIRA AG AND PINHEIRO ML. 2014. Phytochemical study of the alkaloidal fractions of Unonopsis duckei R. E. Fr. guided by electrospray ionisation ion-trap tandem mass spectrometry. Phytochem Anal 25(1): 45-49.

SILVA TP, NOYMA NP, DUQUE TL, GAMALIER JP, VIDAL LO, LOBÃO LM, CHIARINI-GARCIA H, ROLAND F AND MELO RC. 2014. Visualizing aquatic bacteria by light and transmission electron microscopy. Antonie van Leeuwenhoek 105(1): 1-14.

SILVA-JÚNIOR IF, OLIVEIRA RG, SOARES IM, ALVIM TC, ASCÊNCIO SD AND MARTINS DTO. 2014. Evaluation of acute toxicity, antibacterial activity, and mode of action of the hydroethanolic extract of Piper umbellatum L. J Ethnopharmacol 151: 137-143.

SIMEÓN S, RÍOS JL AND VILLAR A. 1990. Antimicrobial activity of Annona cherimolia stem bark alkaloids. Pharmazie 45(6): 442-443.

SPENCER ALR AND SPENCER JFT. 2004. Public health microbiology: methods and protocols, 1st ed., New Jersey: Humana Press Inc., 568 p.

STEPANOVIC S, VUKOVIC D, HOLA V, BONAVENTURA G, DJUKIC S AND IRKOVIC IC. 2007. Quantification of biofilm in microtiter plates: overview of testing conditions and practical recommendations for assessment of biofilm production by staphylococci. Acta Pathol Microbiol Immunol Scand 115: 891-899.

SURESH HM, SHIVAKUMAR B AND SHIVAKUMAR SI. 2012. Cytotoxicity of aporphine alkaloids from the roots of Annona reticulata on human cancer cell lines. Int J Plant Res 2(3): 57-60.

SYARIFAH MMS, NURHANAN MY, HAFFIZ JM, ILHAM AM, GETHA K, ASIAH O, NORHAYATI I, SAHIRA HL AND SURYANI SA. 2011. Potential anticancer compound from Cerbera odollam. J Trop For Sci 23(1): 89-96.

TANG Y-L, SHI Y-H, ZHAO W, HAO G AND LE G-W. 2008. Insertion mode of a novel anionic antimicrobial peptide MDpep5 (Val-Glu-Ser-Trp-Val) from Chinese traditional edible larvae of housefly and its effect on surface potential of bacterial membrane. J Pharm Biomed Anal 48: 11871194.

TSAI IL, LIOU YF AND LU ST. 1989. Screening of isoquinoline alkaloids and their derivatives for antibacterial and antifungal activities. Gaoxiong Yi Xue Ke Xue Za Zhi 5(3): 132-145.

VILJANEN P, MATSUNAGA H, KIMURA Y AND VAARA M. 1990. The outer membrane permeability-increasing action of deacylpolymyxins. J Antibiot (Tokyo) 44(5): 517-523.

VILLAR A, MARES M, RIOS JL, CANTON E AND GOBERNADO M. 1987. Antimicrobial activity of benzylisoquinoline alkaloids. Pharmazie 42(4): 248-250. 
VOHORA SB, KUMAR I AND NAQVI SAH. 1975. Phytochemical, pharmacological, antibacterial and antiovulatory studies on Annona squamosa. Planta Med 28: 96-100.

VOLPE DA AND WARREN MK. 2013. Myeloid clonogenic assays for comparison of the in vitro toxicity ofalkylating agents. Toxicol in Vitro 17: 271-277.

WOO MH, CHO KY, ZHANG Y, ZENG L, GU ZM AND MCLAUGHLIN JL. 1995. Asimilobin and cis- and transmurisolinones, novel bioactive annonaceous acetogenins from the seeds of Asimina triloba. J Nat Prod 58(10): 1533-1542.

WOO SH, REYNOLDS MC, SUN NJ, CASSADY JM AND SNAPKA RM. 1997. Inhibition of topoisomerase II by liriodenine. Biochem Pharmacol 54(4): 467-473.

YOU YO, CHOI NY, KANG SY AND KIM KJ. 2013. Antibacterial activity of Rhus javanica against methicillinresistant Staphylococcus aureus. Evid Based Complement and Alternat Med 2013: 1-8. 